\title{
32. OXIDATION FRONTS IN MADEIRA ABYSSAL PLAIN TURBIDITES: PERSISTENCE OF EARLY DIAGENETIC TRACE-ELEMENT ENRICHMENTS DURING BURIAL, SITE 950 ${ }^{1}$
}

\author{
John Thomson, ${ }^{2}$ Ian Jarvis, ${ }^{3}$ Darryl R.H. Green, ${ }^{2}$ and Damon Green ${ }^{3}$
}

\begin{abstract}
The emplacement of organic-rich turbidite units on abyssal plains is commonly followed by the early diagenetic redistribution of redox-sensitive elements. This occurs only at the summit of the turbidite unit, where it is caused by the downward diffusion of seawater oxygen, which continues for as long as each turbidite is in diffusive contact with bottom waters. The duration of this process is generally a few tens of thousands of years on the Madeira Abyssal Plain (MAP), where turbidite emplacement occurs at frequent intervals. The known sequence of redox-sensitive element redistribution peaks around oxidation fronts in turbidites, derived from studies of conventional piston core material sampling the upper few tens of meters of Quaternary sediments on the MAP, is compared here with that in a single turbidite recovered at Site 950, and now buried to 230 mbsf. This unit was deposited during the late Miocene ( $~ 7.6 \mathrm{Ma})$ and has experienced consecutively post-oxic and sulfate-reducing conditions during burial. The organic carbon $\left(\mathrm{C}_{\text {org }}\right)$ profile and $\mathrm{C}_{\text {org }} / \mathrm{S}$ ratio are remarkably similar to those in more recent examples. The labile (nondetrital) fractions of many redox-sensitive elements remain concentrated around a sharp color change from dark green (below) to greenish gray (above), which marks the limit of penetration of oxygen when the turbidite top was exposed on the seafloor. The elements $\mathrm{Cd}, \mathrm{Sb}, \mathrm{Se}, \mathrm{Tl}$, and $\mathrm{V}$ are all still found in peaks immediately below the original oxic/post-oxic boundary although, as in the younger turbidites, the peak maxima are not exactly coincident. Cobalt, $\mathrm{Cu}, \mathrm{Ni}$, and $\mathrm{Zn}$ have apparently moved upward in chromatographic-like fronts, which are seen as thin dark-purple or gray bands in the core. Labile As, $\mathrm{S}$, and $\mathrm{U}$, which were selectively removed from sediment above the color change by the bacterially driven redox processes that accompanied the oxic decomposition of $\mathrm{C}_{\text {org }}$ in the turbidite, have retained their characteristic stepped-concentration profiles. The successive passage through $\sim 130 \mathrm{~m}$ of post-oxic and $\sim 100 \mathrm{~m}$ of sulfate-reducing conditions (each lasting $\sim 3.8 \mathrm{~m}$.y.) has had remarkably little effect on trace-metal distributions.
\end{abstract}

\section{INTRODUCTION}

Distal turbidites dominate the Quaternary sediment record on the Madeira Abyssal Plain (MAP) (Weaver and Rothwell, 1987; De Lange et al., 1987; Weaver et al., 1989), and it has become widely recognized (Middelburg, 1993) that the area forms one of the best natural laboratories for geochemical and sedimentological studies of such redeposited units. One characteristic early diagenetic feature of deep-sea turbidites, first identified in the sediments on this plain, is their potential for extensive diagenetic modification by a progressive oxidation front (Colley et al., 1984). This involves the diffusiondriven oxidation of organic matter in the upper reaches of each turbidite by bottom-water oxygen, a process that continues only for as long as diffusive contact with bottom water is maintained. The level of penetration of oxygen defines a sharp redox discontinuity (the oxic/post-oxic boundary of Berner, 1981), which causes a marked color change in the turbidite (Jarvis and Higgs, 1987; Thomson et al., 1987). The color contrast is most prominent in turbidites containing significant $(>0.3 \%)$ organic carbon $\left(\mathrm{C}_{\text {org }}\right)$, with a change from green (below) to gray or brown (above).

The progressive oxidation front process has been proven by porewater investigations of the two different turbidites that form presentday MAP surface sediment in different areas of the plain (Wilson et al., 1985, 1986). Identification of the front phenomenon has led to a number of studies that investigated its inorganic (Colley and Thomson, 1985, 1990, 1992; Jarvis and Higgs, 1987; Kennedy and Elderfield, 1987; Buckley and Cranston, 1988; Colley et al., 1989; Cran-

${ }^{1}$ Weaver, P.P.E., Schmincke, H.-U., Firth, J.V., and Duffield, W. (Eds.), 1998. Proc. ODP, Sci. Results, 157: College Station, TX (Ocean Drilling Program).

${ }^{2}$ Challenger Division for Seafloor Processes, Southampton Oceanography Centre, European Way, Empress Dock, Southampton SO14 3ZH, United Kingdom.

${ }^{3}$ School of Geological Sciences, Kingston University, Penrhyn Road, Kingston upon Thames, Surrey KT1 2EE, United Kingdom. Correspondence author: I.Jarvis@kingston.ac.uk ston and Buckley, 1990; Colodner et al., 1992; van Os et al., 1993; Rosenthal et al., 1995; De Lange, Chap. 33, this volume) and organic geochemical consequences (Prahl et al., 1989; McArthur et al., 1992; De Lange, 1992a, 1992b; Keil et al., 1994; Cowie et al., 1995, Chap. 34 , this volume; Hoefs et al., Chap. 35, this volume).

Labile fractions of many redox-sensitive elements respond to the contrasting redox environment across the oxic/post-oxic boundary at an oxidation front, and their reconcentration peaks are readily identified (Thomson et al., 1993). This paper establishes the current geochemical status of the sediments with depth at Ocean Drilling Program (ODP) Site 950 by means of pore-water data, and examines the long-term stability of redox-sensitive element enrichments originally formed at an oxidation front in a representative unit. The goal is to elucidate the long-term behavior of the redox-sensitive element enrichments as they encounter the increasingly anoxic conditions of deeper burial in sediments. Knowledge of the behavior of these elements at sedimentological discontinuities is vital for the correct interpretation of paleoenvironmental changes in the geological record, such as those identified at the Cretaceous/Tertiary $(\mathrm{K} / \mathrm{T})$ and other geologically important boundaries (Lowrie et al., 1990; Wallace et al., 1990; Wang et al., 1993). An improved knowledge of the comparative behavior of different elements during burial is required to distinguish primary from diagenetic signals in such studies. Cores from the MAP obtained during Leg 157 provide the first opportunity to compare the persistence or alteration of oxidation-front peaks over geologically significant time scales.

\section{MATERIALS AND METHODS}

Site 950 is located in the southwestern part of the central MAP (Fig. 1) at $31^{\circ} 9.01^{\prime} \mathrm{N}, 25^{\circ} 36.00^{\prime} \mathrm{W}$, at a water depth of $5437.8 \mathrm{~m}$. The site is situated only $25 \mathrm{~km}$ west-southwest of the site of a 34-m-long giant piston core, MD10, which contains a complete turbidite se-

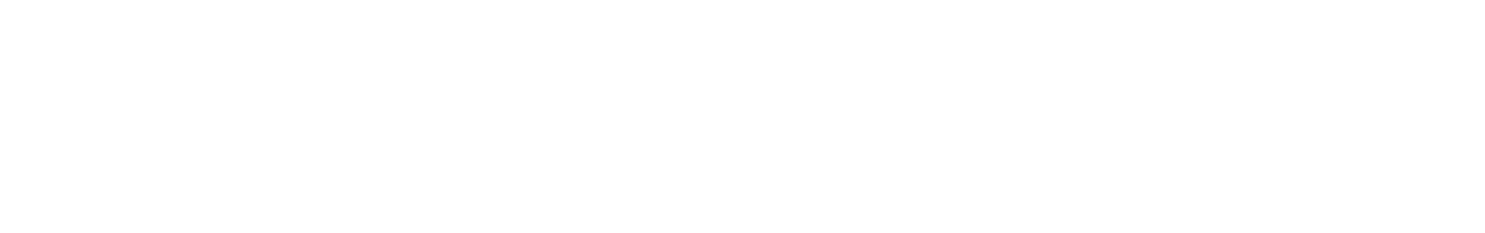




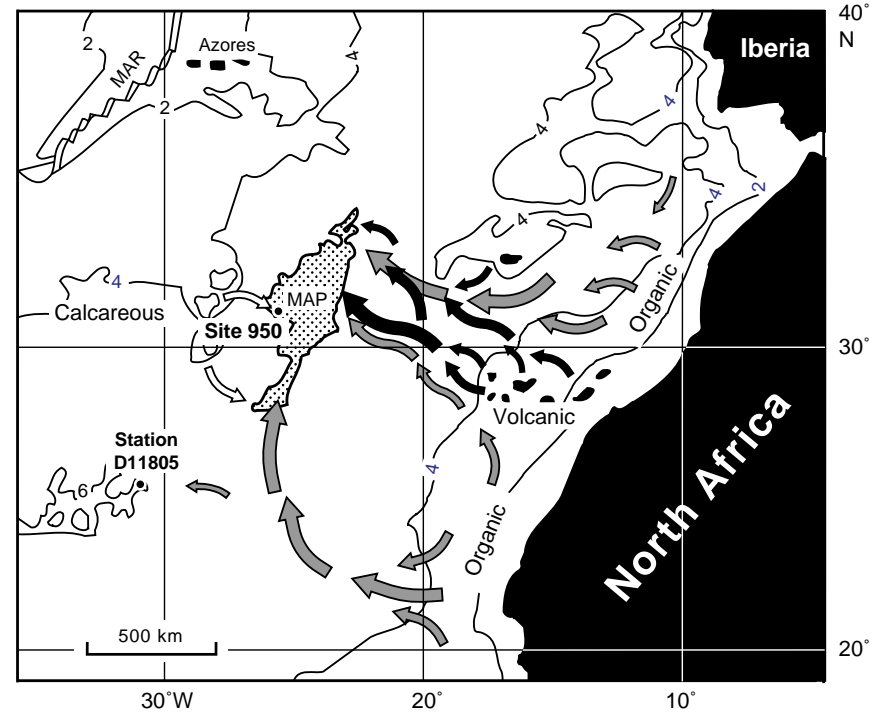

Figure 1. Location map for the Madeira Abyssal Plain (MAP), ODP Site 950, and RRS Discovery Station 11805. MAR = Mid-Atlantic Ridge; bathymetry in kilometers. Sediment transport pathways after Pearce and Jarvis (1995). Gray arrows $=$ organic-rich, black $=$ volcanic, and white $=$ calcareous turbidites.

quence beginning around $690 \mathrm{ka}$ (isotope Stages 1 through 17); this core was geochemically characterized by De Lange et al. (1987, 1989), and was used to demonstrate the application of chemostratigraphic methods to sediment provenance studies. Shipboard (Schmincke, Weaver, Firth, et al., 1995) and subsequent biostratigraphic data (Howe and Sblendorio-Levy, Chap. 29, this volume) demonstrate that Site 950 exhibits a thick and relatively complete turbidite record down to the lowest middle Miocene, and includes a high proportion of thick (up to $6 \mathrm{~m}$ ), green, organic-rich $\left(0.3 \%-2 \% \mathrm{C}_{\mathrm{org}}\right.$ ) mud turbidites to $\sim 306$ meters below seafloor (mbsf). The site was considered, therefore, an ideal focus for a diagenetic study.

\section{Pore-Water Analysis}

Pore-water samples consisted of 5- to 10-cm-long whole-round sections, which were cut and capped immediately after core recovery. A total of 22 samples (Table 1) were obtained between 6 and 354 mbsf at Hole 950A. Pore waters were extracted immediately under ambient shipboard laboratory conditions using titanium squeezers (Manheim and Sayles, 1974), and processed using routine ODP methods (Gieskes et al., 1991). Samples were analyzed for $\mathrm{pH}$, salinity, chlorinity, alkalinity, sulfate, ammonia, sodium, silica, potassium, calcium, and magnesium (see Schmincke, Weaver, Firth, et al., 1995, for details).

\section{Sediment Analysis}

A detailed sediment sampling strategy was necessary for this study because the anticipated elemental enrichment peaks are narrow features. A 2-cm square U-channel sample, selected on criteria described below, was taken from a single organic-rich turbidite in Sample 157-950A-26X-3, 102-150 cm, at a depth of 230.70-231.17 mbsf. The sample was wrapped in plastic film and stored at $4^{\circ} \mathrm{C}$, prior to being returned to the United Kingdom for processing.

Following arrival in the laboratory, the section was sampled in contiguous $1-\mathrm{cm}$ sections (Table 2$)$, dried $\left(105^{\circ} \mathrm{C}\right)$, and ground to a fine powder in a tungsten carbide swing mill. Subsamples $(0.500 \mathrm{~g})$
Table 1. Interstitial-water geochemistry, Hole 950A.

\begin{tabular}{|c|c|c|c|c|}
\hline $\begin{array}{l}\text { Core, section, interval } \\
(\mathrm{cm})\end{array}$ & $\begin{array}{l}\text { Depth } \\
\text { (mbsf) }\end{array}$ & $\begin{array}{l}\text { Alkalinity } \\
(\mathrm{mmol} / \mathrm{L})\end{array}$ & $\begin{array}{c}\mathrm{SO}_{4}{ }^{2-} \\
(\mathrm{mmol} / \mathrm{L})\end{array}$ & $\begin{array}{c}\mathrm{NH}_{4}^{+} \\
(\mu \mathrm{mol} / \mathrm{L})\end{array}$ \\
\hline \multicolumn{5}{|l|}{ 157-950A- } \\
\hline $1 \mathrm{H}-4,145-150$ & 5.87 & 4.81 & 27.1 & 152 \\
\hline $2 \mathrm{H}-4,145-150$ & 14.68 & 5.38 & 25.1 & 320 \\
\hline $3 \mathrm{H}-6,145-150$ & 26.00 & 5.52 & 22.6 & 353 \\
\hline $4 \mathrm{H}-5,145-150$ & 35.19 & 6.05 & 21.7 & 435 \\
\hline $5 \mathrm{H}-5,145-150$ & 44.70 & 6.20 & 20.1 & 601 \\
\hline $6 \mathrm{H}-4,145-150$ & 52.43 & 5.83 & 18.0 & 635 \\
\hline $7 \mathrm{H}-3,145-150$ & 60.88 & 4.59 & 16.7 & 685 \\
\hline $8 \mathrm{H}-5,145-150$ & 72.95 & 4.66 & 14.8 & 785 \\
\hline $9 \mathrm{H}-4,145-150$ & 81.26 & 4.13 & 13.7 & 873 \\
\hline $10 \mathrm{H}-4,145-150$ & 89.50 & 4.10 & 13.7 & 823 \\
\hline $12 \mathrm{H}-4,145-150$ & 109.69 & 4.21 & 10.1 & 978 \\
\hline $14 \mathrm{H}-4,145-150$ & 128.88 & 3.83 & 7.94 & 1040 \\
\hline $16 \mathrm{H}-4,145-150$ & 147.67 & 3.95 & 7.18 & 949 \\
\hline $18 X-2,145-150$ & 156.50 & 3.69 & 6.55 & 871 \\
\hline $20 \mathrm{X}-4,140-150$ & 176.06 & 3.46 & 7.36 & 710 \\
\hline $22 \mathrm{X}-3,140-150$ & 192.51 & 3.19 & 6.06 & 886 \\
\hline $25 \mathrm{X}-3,140-150$ & 221.57 & 3.14 & 6.68 & 767 \\
\hline $27 X-5,145-150$ & 243.77 & 3.63 & 5.53 & 700 \\
\hline $30 X-4,140-150$ & 271.21 & 3.70 & 6.12 & 598 \\
\hline $33 X-5,140-150$ & 301.70 & ND & 7.72 & 324 \\
\hline $36 \mathrm{X}-2,140-150$ & 326.02 & ND & 11.8 & 450 \\
\hline $39 X-1,140-150$ & 353.74 & ND & 10.8 & 261 \\
\hline
\end{tabular}

Notes: Analytical data from Schmincke, Weaver, Firth, et al. (1995). Depths corrected for voids and excess core lengths (after Lebreiro, pers. comm., 1995). ND = not determined because of insufficient pore water.

were initially dissolved by mixed-acid $\left(\mathrm{HF}-\mathrm{HClO}_{4}\right)$ attack in open polytetrafluoroethylene (PTFE) vessels (following the method of Jarvis, 1992). After evaporation to near dryness, residues were dissolved in $10 \mathrm{~mL} 5 \mathrm{M} \mathrm{HNO}_{3}$, and diluted to $50 \mathrm{~mL}$ with deionized water. Solutions were analyzed by simultaneous inductively coupled plasma-atomic emission spectroscopy (ICP-AES) at the Southampton Oceanography Centre for 24 elements (Tables 2, 3), including Ti, $\mathrm{Al}, \mathrm{Fe}, \mathrm{Mn}, \mathrm{Ca}, \mathrm{K}, \mathrm{Co}, \mathrm{Cu}, \mathrm{Ni}, \mathrm{Sc}, \mathrm{V}$, and $\mathrm{Zn}$. Tenfold dilutions of the same solutions were analyzed subsequently by ICP-mass spectrometry (ICP-MS) at the National Environment Research Council (NERC) Facility, Imperial College at Silwood Park, for heavier, less abundant elements; a single isotope was used in each case for quantification $\left({ }^{114} \mathrm{Cd},{ }^{205} \mathrm{Tl},{ }^{208} \mathrm{~Pb},{ }^{232} \mathrm{Th}\right.$, and $\left.{ }^{238} \mathrm{U}\right)$. Separate 0.500 -g subsamples were treated with hot aqua regia (Kuldvere, 1989), and the leachates analyzed by hydride-generation ICP-AES (As, Sb, and Se); $\mathrm{S}$ was determined in these solutions by solution-nebulization ICPAES. The ICP-MS, hydride-element, and S analyses, were based on a subset of available samples (Table 3), selected following the acquisition of ICP-AES data, to reduce analytical effort. Analytical precision was generally in the range 3\%-5\% for ICP-AES, and $5 \%-10 \%$ for ICP-MS. By reference to determinations of certified reference materials, absolute accuracy was judged to be within the limits of the precision.

$\mathrm{CaCO}_{3}$ and $\mathrm{C}_{\text {org }}$ were determined by coulometric analysis of selected samples (Table 2). Carbonate was measured via the $\mathrm{CO}_{2}$ evolved on $\mathrm{H}_{3} \mathrm{PO}_{4}$ acid hydrolysis, and $\mathrm{C}_{\text {org }}$ by the difference between the total $\mathrm{CO}_{2}$ from $900^{\circ} \mathrm{C}$ combustion and carbonate- $\mathrm{CO}_{2}$. All samples were measured in duplicate, and the precision (relative standard deviation) for repeated analysis of a single sample was $3 \%$ for $\mathrm{C}_{\text {org }}$ and $0.3 \%$ for $\mathrm{CaCO}_{3}$.

\section{RESULTS AND DISCUSSION \\ Pore-Water Environments}

Berner's (1981) classification of environments envisages that the geochemical condition of deep-sea sediments becomes progressively more anoxic with increasing depth. This is a consequence of the available electron acceptors for organic-matter oxidation being consumed consecutively in order of decreasing thermodynamic advan- 
Table 2. Major-element geochemistry, Section 157-950A-26X-3.

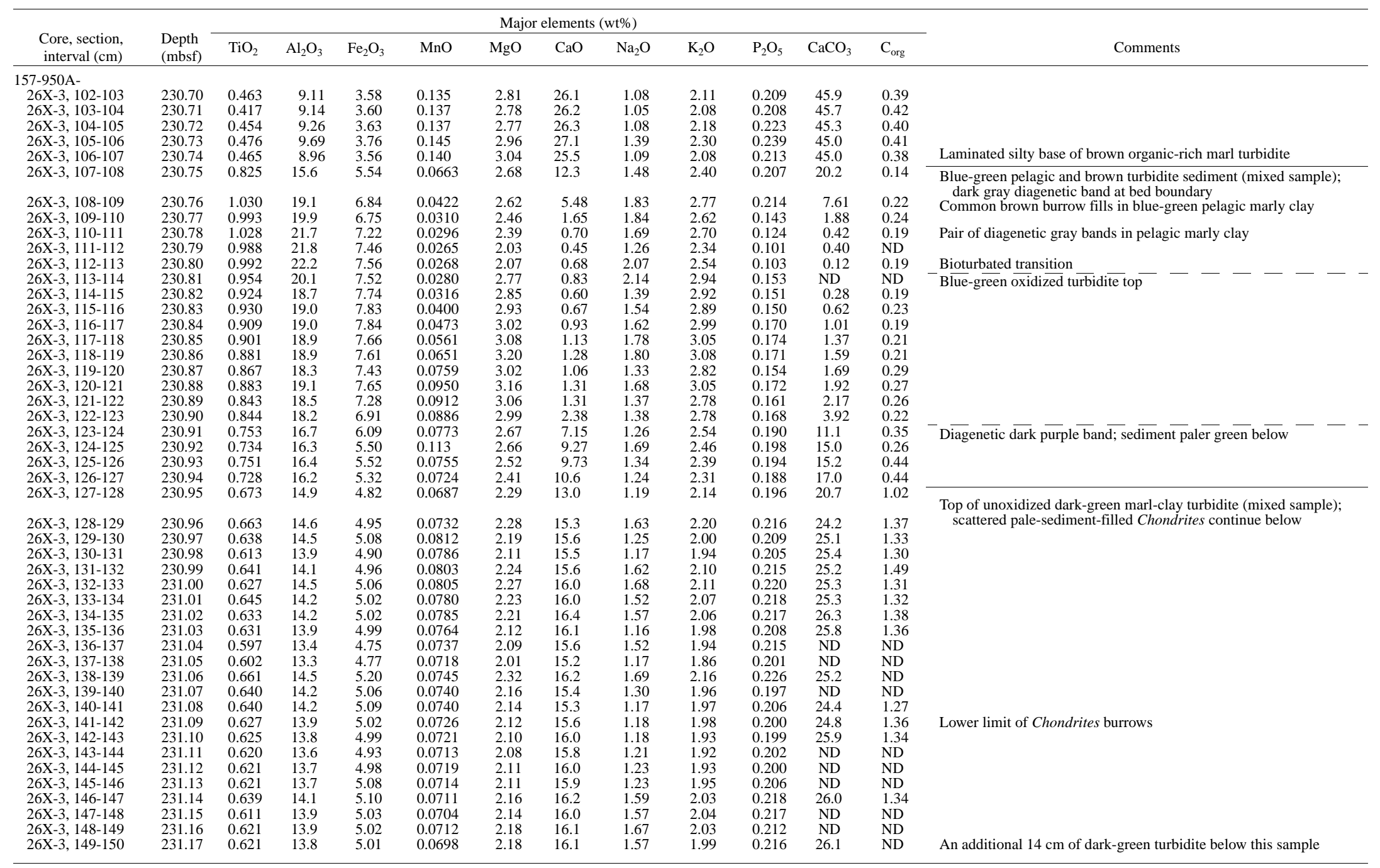

tes: $\mathrm{C}_{\mathrm{org}}=$ organic carbon $\mathrm{SiO}$ detrmination precluded by the sample preparation method. $\mathrm{ND}=$ not determined. Solid and dashed lines $=$ positions of main lithologic changes. Solid lines $=$ sharp bounduies and dashed lines $=$ transitional boundaries. The nature of each is deccribed by the underlying text All datation precluded by the 
Table 3. Trace-element geochemistry, Section 157-950A-26X-3.

\begin{tabular}{|c|c|c|c|c|c|c|c|c|c|c|c|c|c|c|c|c|c|c|c|}
\hline \multirow{2}{*}{$\begin{array}{l}\text { Core, section, } \\
\text { interval }(\mathrm{cm})\end{array}$} & \multirow{2}{*}{$\begin{array}{l}\text { Depth } \\
\text { (mbsf) }\end{array}$} & \multicolumn{18}{|c|}{ Trace elements $(\mu \mathrm{g} / \mathrm{g})$} \\
\hline & & As & Co & $\mathrm{Cd}$ & $\mathrm{Cu}$ & $\mathrm{Li}$ & $\mathrm{Ni}$ & $\mathrm{Pb}$ & $\mathrm{S}$ & $\mathrm{Sb}$ & $\mathrm{Sc}$ & $\mathrm{Se}$ & $\mathrm{Sr}$ & Th & $\mathrm{Tl}$ & $\mathrm{U}$ & $\mathrm{V}$ & $\mathrm{Y}$ & $\mathrm{Zn}$ \\
\hline \multicolumn{20}{|l|}{$157-950 \mathrm{~A}-$} \\
\hline $26 \mathrm{X}-3,102-103$ & 230.70 & ND & 18.5 & 0.30 & 26.1 & 37.1 & 39.5 & 11.1 & ND & ND & 9.0 & ND & 777 & 6.53 & 0.45 & 2.21 & 80.7 & 9.37 & 57.1 \\
\hline $26 \mathrm{X}-3,103-104$ & 230.71 & ND & 18.3 & 0.24 & 27.1 & 43.8 & 38.9 & 10.3 & ND & ND & 9.0 & ND & 776 & 6.15 & 0.43 & 1.99 & 81.7 & 9.30 & 57.7 \\
\hline $26 \mathrm{X}-3,104-105$ & 230.72 & ND & 20.7 & 0.13 & 26.9 & 43.1 & 37.1 & 9.50 & ND & ND & 9.1 & ND & 785 & 6.06 & 0.44 & 2.01 & 83.6 & 9.16 & 56.4 \\
\hline $26 \mathrm{X}-3,105-106$ & 230.73 & ND & 20.6 & 0.26 & 28.6 & 45.1 & 38.5 & 9.90 & ND & ND & 9.8 & ND & 804 & 6.05 & 0.47 & 2.06 & 87.5 & 8.56 & 59.9 \\
\hline $\begin{array}{l}26 \mathrm{X}-3,106-107 \\
2007\end{array}$ & 230.74 & ND & 15.0 & 0.25 & $\begin{array}{l}20.0 \\
26.9\end{array}$ & 42.3 & 36.1 & 9.70 & ND & ND & $\begin{array}{l}9.0 \\
8.9\end{array}$ & ND & 712 & $\begin{array}{l}0.23 \\
6.24\end{array}$ & 0.51 & 1.99 & 81.6 & $\begin{array}{l}0.00 \\
8.87\end{array}$ & 58.5 \\
\hline $26 \mathrm{X}-3,107-108$ & 230.75 & ND & 33.7 & 0.18 & 171 & 72.7 & 61.0 & 20.0 & ND & ND & $\begin{array}{l}0.9 \\
15.0\end{array}$ & ND & 440 & 10.4 & 0.68 & 1.73 & $\begin{array}{l}01.0 \\
127\end{array}$ & $\begin{array}{l}0.07 \\
1.81\end{array}$ & 104 \\
\hline $26 \mathrm{X}-3,108-109$ & 230.76 & ND & 24.2 & 0.06 & 92.5 & 107 & 59.9 & 26.1 & ND & ND & 19.0 & ND & 280 & 12.9 & 0.67 & 1.98 & 147 & 0.77 & 91.0 \\
\hline $26 \mathrm{X}-3,109-110$ & 230.77 & ND & 22.0 & 0.07 & 101 & 103 & 53.3 & $\begin{array}{l}20.1 \\
26.2\end{array}$ & ND & ND & 18.6 & ND & 154 & 13.5 & 0.61 & 1.77 & 144 & 0.39 & 89.5 \\
\hline $26 \mathrm{X}-3,110-111$ & 230.78 & 1.80 & 25.7 & 0.24 & 179 & 108 & 59.1 & 25.9 & 3210 & 0.50 & $\begin{array}{l}19.0 \\
19.8\end{array}$ & ND & 154 & 13.4 & 0.60 & 1.71 & 149 & 0.33 & 126 \\
\hline $26 \mathrm{X}-3,111-112$ & 230.79 & 1.12 & 20.4 & 0.17 & 42.9 & 119 & 49.2 & 23.0 & 3070 & 0.57 & 19.2 & ND & 117 & 12.7 & 0.52 & 1.66 & 136 & 0.25 & 78.4 \\
\hline $26 \mathrm{X}-3,112-113$ & 230.80 & 1.13 & 21.6 & 0.01 & 36.3 & 135 & 47.2 & 24.3 & 3150 & 0.43 & 19.0 & $<0.05$ & 164 & 14.2 & 0.55 & 1.91 & 132 & 0.33 & 75.4 \\
\hline $26 \mathrm{X}-3,113-114$ & 230.81 & 1.30 & 22.4 & 0.16 & 36.6 & 113 & 51.2 & 20.1 & 3140 & 0.23 & 19.7 & $<0.05$ & 132 & 12.5 & 0.54 & 1.68 & 134 & 0.33 & 86.6 \\
\hline $26 \mathrm{X}-3,114-115$ & 230.82 & 1.45 & 20.1 & 0.11 & 36.7 & 92.9 & 55.2 & 21.0 & 3550 & 0.43 & 19.2 & $<0.05$ & 134 & 12.7 & 0.59 & 1.84 & 132 & 0.38 & 101 \\
\hline $26 \mathrm{X}-3,115-116$ & 230.83 & 1.71 & 19.0 & 0.05 & 37.6 & 75.3 & 53.3 & 21.2 & 3950 & 0.30 & 18.5 & $<0.05$ & 134 & 13.2 & 0.59 & 2.14 & 135 & 0.67 & 96.4 \\
\hline $26 \mathrm{X}-3,116-117$ & 230.84 & 1.77 & 18.1 & 0.12 & 35.3 & 86.4 & 52.3 & 18.6 & 4070 & 0.26 & 19.0 & $<0.05$ & 158 & 11.8 & 0.52 & 1.87 & 130 & 0.44 & 97.7 \\
\hline $26 \mathrm{X}-3,117-118$ & 230.85 & 1.44 & 19.4 & 0.18 & 33.4 & 91.7 & 53.3 & 22.2 & 3480 & 0.24 & 18.9 & 0.08 & 172 & $\begin{array}{l}11.0 \\
14.0\end{array}$ & 0.55 & $\begin{array}{l}1.01 \\
2.37\end{array}$ & 132 & 0.48 & 94.9 \\
\hline $26 \mathrm{X}-3,118-119$ & 230.86 & $\begin{array}{l}1.44 \\
1.35\end{array}$ & $\begin{array}{l}18.4 \\
18.0\end{array}$ & $\begin{array}{l}0.10 \\
0.14\end{array}$ & 31.9 & 91.5 & 50.3 & 17.2 & 3360 & 0.26 & $\begin{array}{l}10.9 \\
18.7\end{array}$ & $<0.05$ & 163 & $\begin{array}{l}11.0 \\
11.7\end{array}$ & 0.59 & 2.00 & 131 & 0.45 & 90.4 \\
\hline $26 \mathrm{X}-3,119-120$ & 230.87 & 1.12 & 18.8 & 0.11 & 30.6 & 85.0 & 49.5 & 16.6 & 3180 & 0.25 & $\begin{array}{l}18.1 \\
18.1\end{array}$ & $<0.05$ & 139 & 11.6 & 0.49 & 2.03 & 132 & 0.42 & 90.6 \\
\hline $26 \mathrm{X}-3,120-121$ & 230.88 & 1.68 & 19.9 & 0.10 & 29.4 & 88.8 & 56.7 & 16.3 & 3630 & 0.20 & 18.4 & 0.09 & 171 & 11.3 & 0.52 & 2.09 & 139 & 0.47 & 100 \\
\hline $26 \mathrm{X}-3,121-122$ & 230.89 & 1.54 & 18.6 & 0.11 & 27.5 & 89.1 & 53.6 & 16.2 & 3070 & 0.15 & 17.9 & 0.07 & 148 & 11.5 & 0.59 & 2.18 & 139 & 0.43 & 91.8 \\
\hline $26 \mathrm{X}-3,122-123$ & 230.90 & 1.42 & 17.8 & 0.16 & 33.4 & 88.1 & 52.8 & 16.6 & 2670 & 0.16 & 17.6 & 0.11 & 178 & 12.1 & 0.56 & 2.26 & 136 & 0.54 & 95.9 \\
\hline $26 \mathrm{X}-3,123-124$ & 230.91 & 1.52 & 23.5 & 0.11 & 124 & $\begin{array}{l}00.1 \\
78.8\end{array}$ & 68.3 & $\begin{array}{l}10.0 \\
17.6\end{array}$ & 2070 & 0.35 & $\begin{array}{l}16.0 \\
16.0\end{array}$ & 0.23 & 315 & 12.0 & 0.76 & 2.47 & 127 & 1.13 & 107 \\
\hline $26 \mathrm{X}-3,124-125$ & 230.92 & 0.75 & 17.8 & 0.15 & 57.8 & 75.2 & 47.4 & 13.8 & 925 & 0.29 & 15.6 & 0.15 & 376 & 10.1 & 0.48 & 2.06 & 125 & 1.41 & 85.5 \\
\hline $26 \mathrm{X}-3,125-126$ & 230.93 & 0.61 & 18.0 & 0.14 & 59.5 & 77.3 & 46.6 & 16.0 & 872 & 0.36 & 15.5 & 0.23 & 390 & 11.0 & 0.57 & 2.24 & 130 & 1.45 & 81.8 \\
\hline $26 \mathrm{X}-3,126-127$ & 230.94 & 0.78 & 21.2 & 0.22 & 69.5 & 79.2 & 50.7 & 16.4 & 891 & 0.69 & 15.2 & 0.81 & 420 & 11.7 & 0.58 & 2.54 & 135 & 1.60 & 89.3 \\
\hline $26 \mathrm{X}-3,127-128$ & 230.95 & 1.00 & 20.4 & 0.41 & 83.0 & 71.3 & 49.5 & 14.8 & 940 & 0.98 & 14.3 & 4.17 & 490 & 9.97 & 0.67 & 3.02 & 130 & 2.20 & 86.2 \\
\hline $26 \mathrm{X}-3,128-129$ & 230.96 & 4.35 & 18.7 & 3.88 & 58.8 & 77.8 & 58.2 & 14.1 & 3710 & 1.13 & 13.8 & 4.10 & 583 & 9.51 & 0.82 & 4.06 & 143 & 2.73 & 91.4 \\
\hline $26 \mathrm{X}-3,129-130$ & 230.97 & 6.46 & 19.7 & 0.49 & 41.8 & 60.4 & 65.0 & 12.3 & 5180 & 0.97 & 13.7 & 1.36 & 573 & 8.88 & 0.99 & 4.97 & 120 & 2.75 & 82.3 \\
\hline $26 \mathrm{X}-3,130-131$ & 230.98 & $\begin{array}{l}0.40 \\
7.02\end{array}$ & 19.5 & 0.43 & $\begin{array}{l}1.0 \\
40.3\end{array}$ & $\begin{array}{l}70.4 \\
70.3\end{array}$ & 62.8 & 13.3 & 5240 & 0.68 & 13.1 & $\begin{array}{l}1.50 \\
1.10\end{array}$ & 553 & $\begin{array}{l}0.00 \\
9.22\end{array}$ & 0.91 & 5.49 & 112 & 2.87 & 76.2 \\
\hline $26 \mathrm{X}-3,131-132$ & $\begin{array}{l}230.98 \\
230.99\end{array}$ & 6.75 & 20.8 & $\begin{array}{l}0.43 \\
0.43\end{array}$ & 41.7 & 71.1 & $\begin{array}{l}0.8 \\
67.4\end{array}$ & 12.5 & 5070 & $\begin{array}{l}0.08 \\
0.69\end{array}$ & $\begin{array}{l}11.1 \\
13.4\end{array}$ & 0.96 & 554 & 8.71 & 0.78 & $\begin{array}{l}5.49 \\
5.45\end{array}$ & 113 & 2.78 & 76.0 \\
\hline $26 \mathrm{X}-3,132-133$ & 231.00 & 7.66 & 22.5 & 0.39 & 41.9 & 67.2 & 66.7 & 12.9 & 4830 & 0.41 & 13.9 & 0.94 & 576 & 8.78 & 0.70 & 5.80 & 114 & 2.75 & 78.3 \\
\hline $26 \mathrm{X}-3,133-134$ & 231.01 & 7.46 & 21.1 & 0.36 & 41.7 & 73.0 & 69.2 & 14.1 & 4880 & 0.65 & 13.6 & 0.86 & 583 & 9.81 & 0.67 & 6.49 & 112 & 2.90 & 77.1 \\
\hline $26 \mathrm{X}-3,134-135$ & 231.02 & 8.45 & 20.1 & 0.49 & 40.4 & 73.2 & 71.1 & 12.1 & 5800 & 0.43 & 13.5 & 0.87 & 581 & 8.97 & 0.62 & 5.91 & 112 & 2.90 & 78.3 \\
\hline $26 \mathrm{X}-3,135-136$ & 231.03 & 8.51 & 19.5 & 0.42 & 40.3 & 69.0 & 68.8 & 13.7 & 5900 & 0.39 & 13.3 & 0.95 & 571 & 9.60 & 0.63 & 6.32 & 108 & 2.94 & 76.8 \\
\hline $26 \mathrm{X}-3,136-137$ & 231.04 & $\begin{array}{l}.0 .51 \\
9.54\end{array}$ & 20.3 & 0.37 & 38.1 & 63.1 & $\begin{array}{l}64.0 \\
64.1\end{array}$ & 12.0 & 6020 & 0.36 & 12.7 & 0.88 & 553 & 8.21 & 0.49 & $\begin{array}{l}0.32 \\
5.40\end{array}$ & $\begin{array}{l}103 \\
103\end{array}$ & 3.10 & 72.5 \\
\hline $26 \mathrm{X}-3,137-138$ & 231.05 & 8.97 & 18.2 & 0.45 & 38.2 & 62.7 & 63.9 & 12.5 & 5970 & 0.29 & 12.5 & 0.88 & 548 & 9.15 & 0.60 & 5.76 & 102 & 3.11 & 71.9 \\
\hline $26 \mathrm{X}-3,138-139$ & 231.06 & 9.31 & 24.8 & 0.42 & 44.2 & 81.1 & 65.1 & 13.9 & 4390 & 0.31 & 13.9 & 0.81 & 574 & 9.41 & 0.55 & 5.67 & 112 & 2.74 & 78.8 \\
\hline $26 \mathrm{X}-3,139-140$ & 231.07 & 9.54 & 20.4 & 0.55 & 40.2 & 54.9 & 66.0 & 15.0 & 5870 & 0.28 & 13.4 & 0.95 & 557 & 10.4 & 0.62 & 6.41 & 106 & 2.77 & 75.2 \\
\hline $26 \mathrm{X}-3,140-141$ & 231.08 & 10.2 & 19.3 & 0.33 & 40.9 & 57.3 & 63.2 & 14.2 & 6130 & 0.27 & 13.5 & 0.84 & 556 & 9.80 & 0.57 & 6.05 & 107 & 2.76 & 75.9 \\
\hline $26 \mathrm{X}-3,141-142$ & 231.09 & 10.7 & 19.8 & 0.46 & 40.9 & 67.9 & 62.7 & 12.2 & 6050 & 0.21 & 13.2 & 0.82 & 557 & 8.93 & 0.46 & 5.50 & 107 & 2.88 & 75.3 \\
\hline $26 \mathrm{X}-3,142-143$ & 231.10 & $\begin{array}{l}10.7 \\
10.7\end{array}$ & $\begin{array}{l}19.0 \\
17.6\end{array}$ & 0.46 & $\begin{array}{l}40.9 \\
39.7\end{array}$ & 63.4 & 63.7 & 12.2 & 6080 & 0.28 & 13.1 & 0.84 & 567 & $\begin{array}{l}8.93 \\
8.91\end{array}$ & $\begin{array}{l}0.40 \\
0.50\end{array}$ & 5.47 & 104 & 2.90 & 74.4 \\
\hline $26 \mathrm{X}-3,143-144$ & 231.11 & $\begin{array}{l}10.1 \\
11.7\end{array}$ & $\begin{array}{l}11.0 \\
19.0\end{array}$ & $\begin{array}{l}0.40 \\
0.44\end{array}$ & 39.2 & $\begin{array}{l}0.4 \\
65.6\end{array}$ & $\begin{array}{l}60.3 \\
60.3\end{array}$ & 13.1 & $\begin{array}{l}0000 \\
5900\end{array}$ & $\begin{array}{l}0.28 \\
0.32\end{array}$ & $\begin{array}{l}11.1 \\
12.9\end{array}$ & 0.86 & $\begin{array}{l}501 \\
561\end{array}$ & $\begin{array}{l}8.91 \\
9.83\end{array}$ & 0.55 & 5.85 & 103 & 3.03 & $\begin{array}{l}17.4 \\
72.9\end{array}$ \\
\hline $26 \mathrm{X}-3,144-145$ & 231.12 & 11.8 & 22.3 & 0.47 & 40.0 & 67.0 & 60.6 & 13.2 & 6010 & 0.25 & 13.0 & 0.80 & 571 & 9.52 & 0.55 & 6.29 & 105 & 3.03 & 73.9 \\
\hline $26 \mathrm{X}-3,145-146$ & 231.13 & 14.9 & 19.7 & 0.54 & 40.1 & 68.5 & 63.7 & 12.7 & 6900 & 0.34 & 13.0 & 0.88 & 564 & 8.79 & 0.52 & 5.5 & 104 & 2.99 & 74.8 \\
\hline $26 \mathrm{X}-3,146-147$ & 231.14 & ND & 21.5 & 0.49 & 40.1 & 61.5 & 63.3 & 12.1 & ND & $\mathrm{ND}$ & 13.2 & $\mathrm{ND}$ & 602 & 8.83 & 0.55 & 5.0 & 106 & 3.0 & 79.2 \\
\hline $26 \mathrm{X}-3,147-148$ & 231.15 & ND & 20.7 & 0.47 & 39.6 & 65.7 & 64.7 & 11.8 & ND & ND & 13.0 & ND & 598 & $\begin{array}{l}0.03 \\
8.44\end{array}$ & 0.5 & 5. & 105 & 3.08 & 74.7 \\
\hline $26 \mathrm{X}-3,148-149$ & 231.16 & ND & 19.5 & 0.30 & 39.8 & 72.0 & 63.6 & 13.4 & ND & ND & 13.2 & ND & 571 & 9.61 & 0.49 & 3.96 & 107 & 2.96 & 74.9 \\
\hline $26 \mathrm{X}-3,149-150$ & 231.17 & ND & 21.1 & 0.34 & 39.9 & 63.7 & 61.0 & 12.4 & ND & ND & 13.2 & ND & 587 & 8.82 & 0.51 & 5.00 & 104 & 3.08 & 74.1 \\
\hline
\end{tabular}

Note: $\mathrm{ND}=$ not determined . 
tage: pore-water $\mathrm{O}_{2}$; pore-water $\mathrm{NO}_{3}{ }^{-}$; solid-phase $\mathrm{Mn}$ and $\mathrm{Fe}$ oxyhydroxides; and pore-water $\mathrm{SO}_{4}{ }^{2-}$ (Froelich et al. 1979). If buried beyond the sulfate-reduction zone, labile organic matter can be further degraded by methanogenic bacteria at temperatures up to at least $70^{\circ} \mathrm{C}$ ( $\sim 2 \mathrm{~km}$ depth; Emery and Robinson, 1993). The classification (Berner, 1981) is based on pore-water $\mathrm{O}_{2}$ and $\mathrm{H}_{2} \mathrm{~S}$ concentrations and defines a sequence of oxic, post-oxic, sulfidic, and methanic environments with increasing depth.

Oxic conditions persist to only $20-30 \mathrm{~cm}$ on the MAP because organic-rich Holocene turbidites form the present sediment surface (Wilson et al., 1985, 1986; Thomson et al., 1987, 1989). The characteristic feature of these surficial turbidites is the sharpness of the oxic/ post-oxic boundary, with pore-water $\mathrm{O}_{2}$ and $\mathrm{NO}_{3}{ }^{-}$both completely consumed at the color change, and $\mathrm{Mn}^{2+}, \mathrm{Fe}^{2+}$, and $\mathrm{NH}_{4}{ }^{+}$all present in solution only immediately below. By contrast, pore-water $\mathrm{SO}_{4}{ }^{2-}$ contents fall continuously (Fig. 2; Table 1), more or less linearly, over the upper $150 \mathrm{~m}$ in Hole $950 \mathrm{~A}$, from a initial value similar to bottom water $(\sim 29 \mathrm{mmol} / \mathrm{L})$ to $\sim 6-7 \mathrm{mmol} / \mathrm{L}$, a level that is maintained from 150-270 mbsf.

Declining sulfate is matched by increasing alkalinity to a maximum of $>6 \mathrm{mmol} / \mathrm{L} \sim 50 \mathrm{mbsf}$ (Fig. 2), caused by $\mathrm{H}_{2} \mathrm{~S}$ and $\mathrm{HCO}_{3}{ }^{-}$production accompanying sulfate reduction. Below $50 \mathrm{mbsf}$, alkalinity falls progressively, largely due to consumption of bicarbonate ions by carbonate precipitation. Unusually, pore-water sulfate values actually increase again slightly below 270 mbsf (MAP Sites 951 and 952 maintain low but finite $\mathrm{SO}_{4}{ }^{2-}$ values below $200 \mathrm{mbsf}$; Schmincke, Weaver, Firth, et al., 1995).

Pore-water $\mathrm{NH}_{4}^{+}$contents in Hole 950A decrease both upward and downward from a maximum $\sim 130 \mathrm{mbsf}$ (Fig. 2). Taken together, the $\mathrm{SO}_{4}{ }^{2-}$ and $\mathrm{NH}_{4}{ }^{+}$profiles imply the onset of sulfate reduction below 130 mbsf in Hole 950A, with $\mathrm{SO}_{4}{ }^{2-}$ consumed to form sulfides and $\mathrm{NH}_{4}{ }^{+}$produced as a reaction by-product. There is insufficient information available to define exactly where the transition between post-oxic and sulfidic conditions occurs. The continued presence of

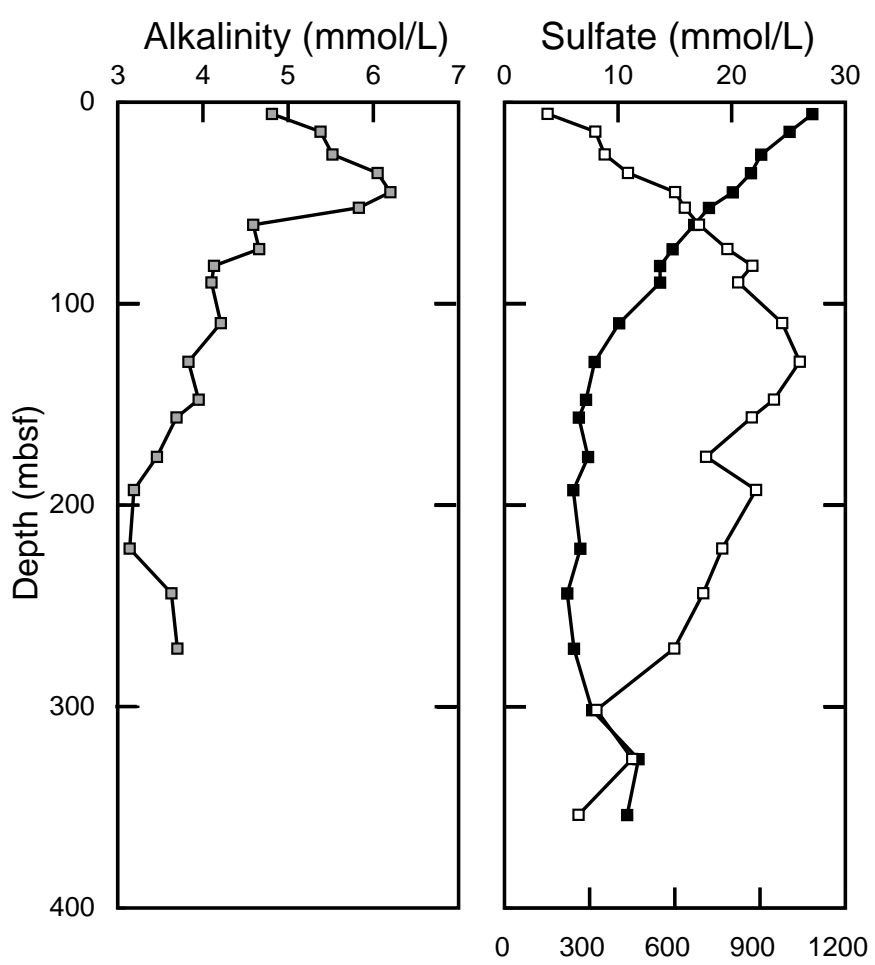

Figure 2. Interstitial water alkalinity, sulfate (solid squares), and ammonia (open squares), Hole 950A (data from Schmincke, Weaver, Firth, et al., 1995). residual $\mathrm{SO}_{4}{ }^{2-}$ at depth, and the absence of significant pore-water $\mathrm{CH}_{4}(<10 \mu \mathrm{g} / \mathrm{mL}$; Schmincke, Weaver, Firth, et al., 1995), indicate that methanogenesis is not active within the drilled interval at Site 950 .

\section{Sample Selection Criteria}

The upper part of the sedimentary sequence at Site 950 from 0 306 mbsf (Unit I) comprises thick (decimeter to meter) turbidite muds separated by thin (centimeter) pelagic ooze, marl, or clay interbeds (Schmincke, Weaver, Firth, et al., 1995). Carbonate debrisflows characterize the interval 306-333 mbsf (Unit II), whereas pelagic red clays, thin turbidites, and ash layers dominate below 333 mbsf (Units II, IV). From experience with more recent MAP sediments (De Lange et al. 1987, 1989; Pearce and Jarvis, 1995), shipboard classification identified three major types of turbidite in Unit I: gray volcanic-rich beds, sourced largely from volcanic islands within the basin (Fig. 1); green organic-rich examples, originating from the northwest African margin; and white calcareous turbidites, derived from seamounts located to the west of the plain.

A single organic-rich turbidite $\left(>0.3 \% \mathrm{C}_{\text {org }}\right)$ was chosen for this study, because this type is enriched in many trace metals on emplacement (Jarvis and Higgs, 1987), and progressive oxidation fronts produce the sharpest and strongest color changes in such units. The premises that guided sample selection were (1) dark-green turbidites are $\mathrm{C}_{\text {org }}$ rich; (2) the presence of a lighter colored top in a dark-green unit indicates that a progressive oxidation front modified the unit after emplacement; and (3) as old a unit as possible would provide the most demanding test of the persistence of relic oxidation-front features. Additional considerations were (4) the oxidatively bleached part of the turbidite should be at least $10 \mathrm{~cm}$ thick to ensure that (a) the turbidite surface had been exposed to seawater oxygen for sufficient time to induce significant trace-metal enrichments and (b) enrichment fronts would be below the main bioturbation zone, which typically extends (Boudreau, 1994) to $10 \mathrm{~cm}$ below the base of the overlying pelagic unit; and (5) there should be at least $30 \mathrm{~cm}$ of unoxidized sediment remaining below the color change, to ensure that any enrichments within this interval were not masked by their occurrence in a coarser grained basal facies, or even an underlying unit, with a different bulk composition.

The unit selected on these criteria was Sample 157-950A-26X-3, $102-150 \mathrm{~cm}$, at a depth of $230.70-231.17 \mathrm{mbsf}$, and referred to the upper Miocene basal CN9b Zone (deposited 7.6 Ma; Howe and Sblendorio-Levy, Chap. 29, this volume). Based on the interpretation of the pore-water data above, the unit has traversed $130 \mathrm{~m}$ of postoxic and $100 \mathrm{~m}$ of sulfate-reducing conditions (each lasting $\sim 3.5$ m.y.) since emplacement.

\section{Lithological and Geochemical Characteristics}

The 50-cm sample section investigated (Table 2) encompassed 5 $\mathrm{cm}$ of basal sediment from an overlying brown (Munsell Color 3Y 4/ 1) turbidite; $6 \mathrm{~cm}$ of mottled blue-green (5G 3/1) pelagic marl; $14 \mathrm{~cm}$ blue-green (5G 3/1) oxidized turbidite top; and $25 \mathrm{~cm}$ of dark-green (1 GY 3/1) unoxidized turbidite body (Fig. 3). The base of the darkgreen turbidite lies $14 \mathrm{~cm}$ below the sampled interval, in the immediately underlying core section. By comparison with recent turbidites that have experienced an oxidation front, these lengths were expected to be sufficient to include any narrow peak enrichments around the relic front, and also to define the background elemental levels above and below the relic front. Using a model based on $\mathrm{O}_{2}$ diffusion, Buckley and Cranston (1988) estimated oxidation periods of 2-15 k.y. (average 5.4 k.y.) for eight Quaternary MAP turbidite units exhibiting sharp color changes. These values are likely to be underestimates, however, because they do not allow sufficient time for deposition of the intervening pelagic units between the turbidites at recent pelagic accumulation rates (Weaver et al., 1992). 


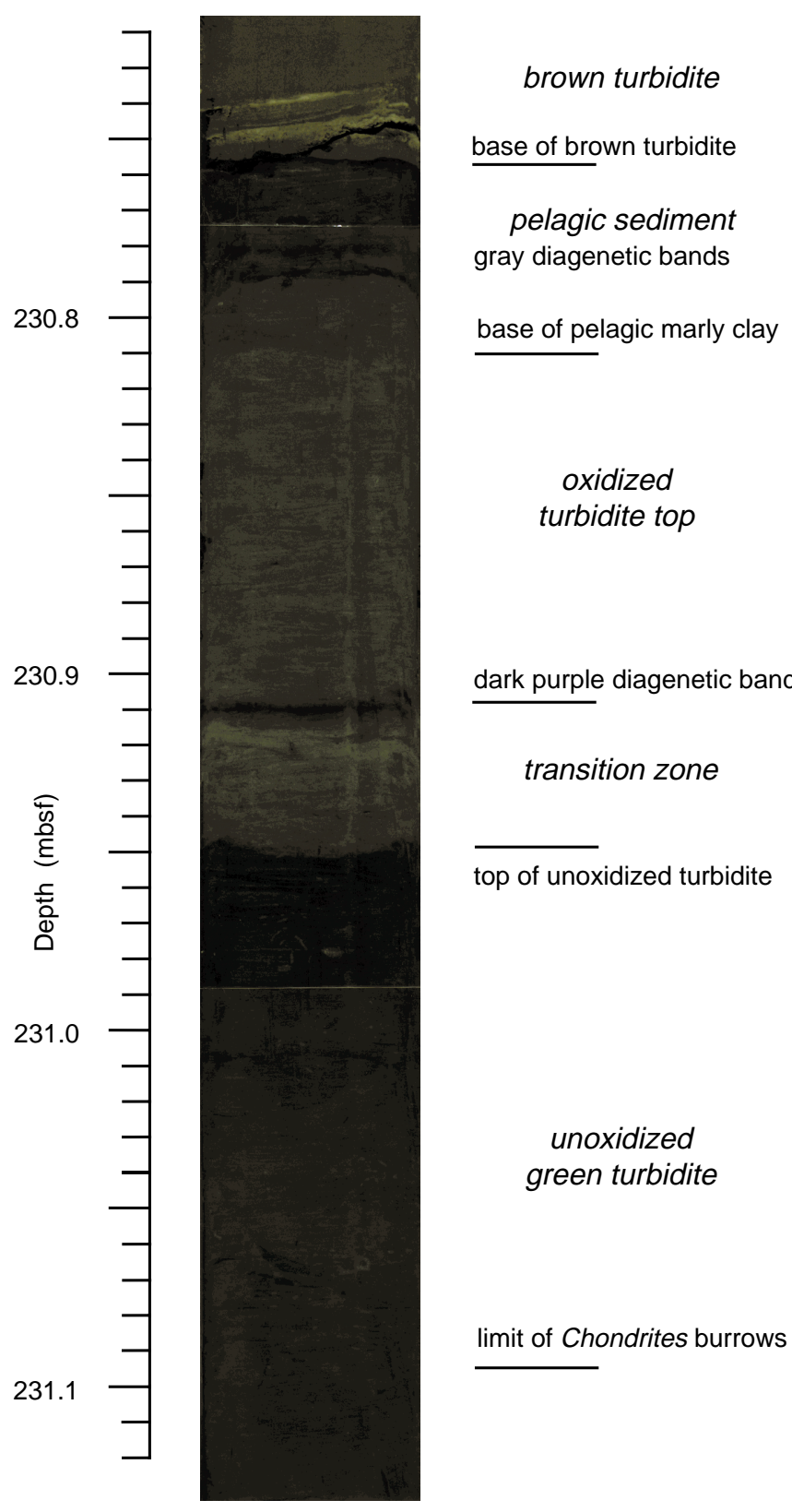

Figure 3. Image of the fossil redox front in Section 157-950A-26X-3. (See CD-ROM version for color image.)

In the absence of any color change, the base of the pelagic marl is difficult to identify, and although prominent burrows occur particularly in the uppermost $3 \mathrm{~cm}$, both indistinct mottling and discrete pale sediment-filled Chondrites burrows occur throughout the blue-green sediments, interpreted to be largely oxidatively bleached turbidite top; indeed, Chondrites extend to $15 \mathrm{~cm}$ below the relic redox front. This combination of a poorly defined inhomogeneous pelagic interval and mixing by bioturbation, is the likely cause of fluctuations in $\mathrm{CaCO}_{3}$ and $\mathrm{Al}_{2} \mathrm{O}_{3}$ contents (Fig. 4) between 230.75 and 230.81 mbsf.

The turbidite has low $\mathrm{C}_{\text {org }}$ values $(0.2 \%)$ in its lighter colored upper part (230.81-230.90 mbsf), contains around $0.4 \% \mathrm{C}_{\text {org }}$ in a paler band from 230.91 to 230.94 (Fig. 4; Table 2), and then much higher and near-constant $\mathrm{C}_{\text {org }}$ values $(1.3 \%)$ in the darker colored lower reaches (below $230.95 \mathrm{mbsf}$ ). The low $\mathrm{C}_{\text {org }}$ data in the turbidite top are accompanied by negligible or very low $\mathrm{CaCO}_{3}$ values $(0.3 \%-$ $4 \%$ ), which rise to $\sim 15 \%$ in the transition zone, and are then consis- tently $\sim 25 \%$ at depths below 230.95 mbsf. These related $\mathrm{C}_{\text {org }}$ and $\mathrm{CaCO}_{3}$ content and color contrasts (Fig. 4) are similar to those noted previously in younger turbidites from the MAP (Jarvis and Higgs, 1987; Cranston and Buckley, 1990; Thomson et al., 1993). The above characteristics are evidence of $\mathrm{CaCO}_{3}$ dissolution in response to the $\mathrm{CO}_{2}$ produced by post-emplacement oxidation of $\mathrm{C}_{\text {org }}$, during the brief period when the selected unit formed the MAP sediment surface (Buckley and Cranston, 1988; Thomson et al., 1993). In this example, there is an unusually large amount of $\mathrm{CaCO}_{3}$ dissolution, in excess of stoichiometry from $\mathrm{C}_{\text {org }}$ oxidation.

In their study of Atlantic Quaternary sequences, Cranston and Buckley (1990) noted that more $\mathrm{CaCO}_{3}$ dissolution accompanies $\mathrm{C}_{\text {org }}$ oxidation in Nares Abyssal Plain turbidites than in MAP turbidites. These workers attributed additional $\mathrm{CaCO}_{3}$ dissolution to greater carbonate undersaturation of the deeper Nares bottom waters. A similar explanation may be advanced for the excess carbonate dissolution observed in this study. Our Miocene ( 7.6 Ma) turbidite lies toward the top of an interval, beginning $\sim 220 \mathrm{mbsf}$, where intervening pelagic units are clays containing $<2 \% \mathrm{CaCO}_{3}$ (Lebriero et al., Chap. 30, this volume), indicating that consistently corrosive bottom waters characterized pelagic deposition before the mid-late Miocene ( 6.7 $\mathrm{Ma}$ ). Younger pelagic sediments on the plain, on the other hand, have mixed pelagic lithologies with variable $\mathrm{CaCO}_{3}$ contents that indicate fluctuating levels of lesser bottom-water carbonate undersaturation. Rate calculations demonstrate that dissolution of turbidite carbonate by undersaturated bottom waters cannot be solely a diffusional process. However, burrowing and more pervasive bioturbation in turbidite tops would have provided a mechanism for physical mixing of bottom and pore waters, which would have enhanced the efficiency of both oxidation and dissolution processes. In support of this, a broad positive correlation exists between burrow densities and the amount of excess carbonate dissolution in organic-rich turbidite tops, as noted by De Lange (Chap. 33, this volume).

On burial into successively more reducing conditions (i.e., after termination of the oxidation front in the selected unit), some further remineralization of $\mathrm{C}_{\text {org }}$ must continue in MAP sediments. Such reaction is necessary to drive the $\mathrm{SO}_{4}{ }^{2-}$ consumption and $\mathrm{NH}_{4}{ }^{+}$production evident in the pore-water data (Fig. 2). In the selected section, the least-degraded $\mathrm{C}_{\text {org }}$ is likely to be present in the deeper parts of the turbidite below the former level of oxidation. Therefore, the uniform high $\mathrm{C}_{\text {org }}$ contents $(\sim 1.3 \%)$ in the unoxidized part of the green turbidite might now be expected to be lower than they were at emplacement. Nevertheless, this is a very high $\mathrm{C}_{\text {org }}$ content for a deep-sea sediment (Waples and Sloan, 1980), particularly 7 m.y. after deposition. If substantial sulfate reduction had occurred in the turbidite, some increase in $\mathrm{S}$ content would be expected. This does not appear to be the case, because the solid-phase $\mathrm{C}_{\text {org }} / \mathrm{S}$ profile of our Miocene example is comparable to that observed previously (Thomson et al., 1993) in core D11805\#1K (Fig. 5), which sampled a 250-ka Quaternary turbidite deposited in a basin $\left(25^{\circ} 40^{\prime} \mathrm{N}, 30^{\circ} 57^{\prime} \mathrm{W}\right.$; Fig. 1) $500 \mathrm{~km}$ to the southwest of the southern MAP. This core exhibited pore-water $\mathrm{SO}_{4}{ }^{2-}$ concentrations similar to those in seawater, so the sulfides present there must have formed in the precursor sediments to the turbidite, presumably on the northwest African continental margin. It is likely that the sulfides at Site 950 are also largely inherited, since $\mathrm{C}_{\text {org }} / \mathrm{S}$ ratios in the unoxidized part of the Miocene turbidite (Fig. 5) are similar to those in its younger counterpart. Paradoxically, despite clear evidence that the turbidite $\mathrm{C}_{\text {org }}$ was initially highly reactive with bottom-water oxygen, and despite the high residual $\mathrm{C}_{\text {org }}$ content and clear pore-water gradients for $\mathrm{SO}_{4}{ }^{2-}$ and $\mathrm{NH}_{4}{ }^{+}$, there is no evidence from the solid phase for subsequent remineralization upon deeper burial.

\section{Redox-Sensitive Element Profiles}

Large changes in $\mathrm{CaCO}_{3}$ content through the formerly oxidized, upper part of the turbidite, mean that it is convenient to display elemental data normalized either to Al (ICP-AES data) or to Th (ICP- 

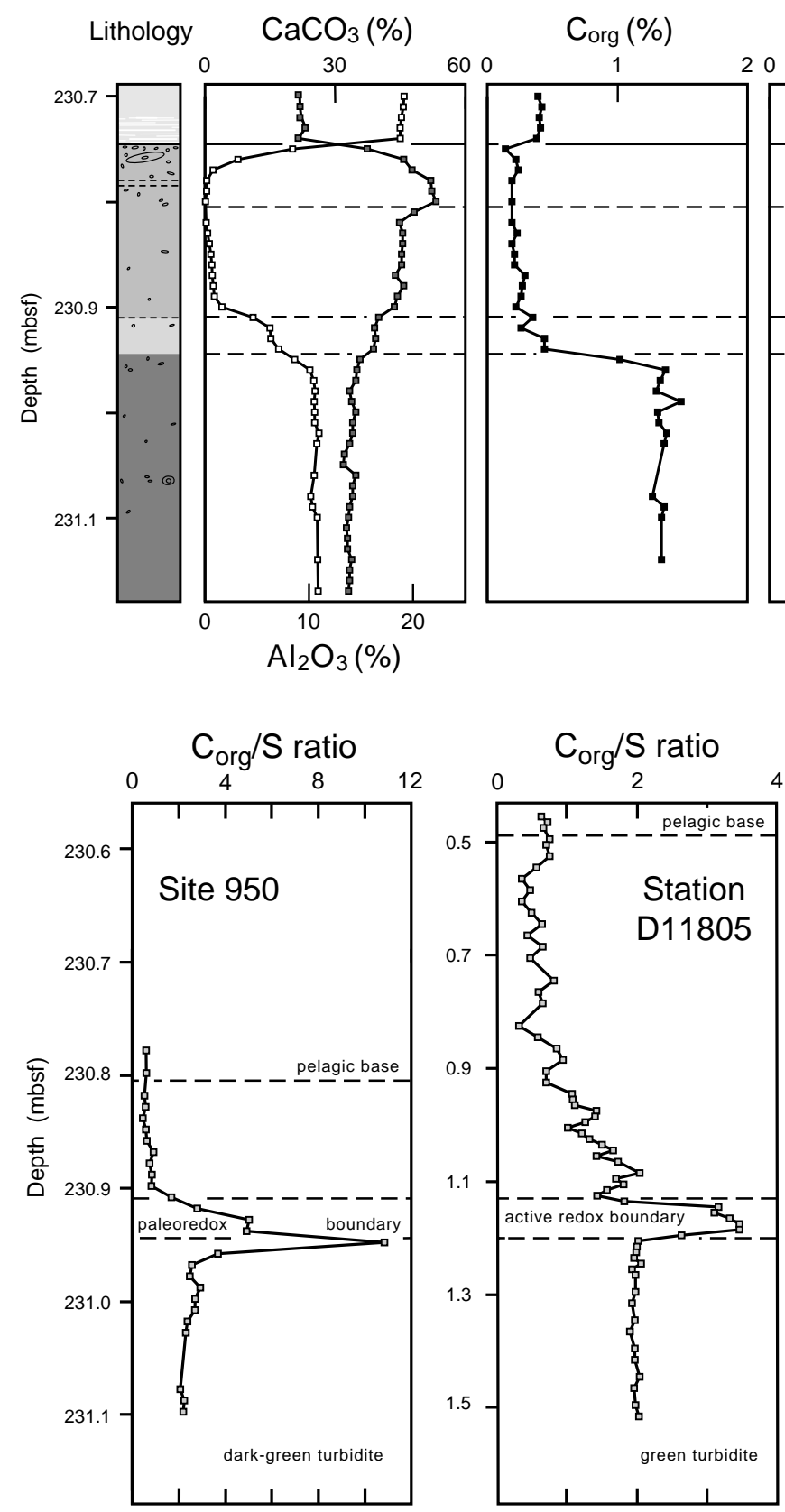

Figure 5. $\mathrm{C}_{\text {org }} / \mathrm{S}$ ratio plots for Section 157-950A-26X-3 and Kastenlot core D11805\#1K. Profiles are aligned with respect to the major color-change representing the position of the redox front; note the different scales. Core D11805\#1K (Thomson et al., 1993) contains a currently active redox front in a thick 250-ka organic-rich turbidite, located approximately $800 \mathrm{~km}$ southwest of Site 950 (see Fig. 1).

MS data). The rationale for this procedure is that biogenic $\mathrm{CaCO}_{3}$ is relatively pure and free from other elements ( $\mathrm{Mg}$ and $\mathrm{Sr}$ excepted), whereas most other elements have finite, approximately constant contents in detrital minerals (clays). If this is the case, then local diagenetic peaks are revealed as increases above regular baseline, detrital $\mathrm{Al}$ or Th ratio values. In the case of the ICP-MS data, normalization to Th also produces a smoothing of minor fluctuations in the original data, which arose from instrument instability during measurement; Al/Th ratios are constant throughout the section, so the choice of normalization element has no affect on the geochemical trends.

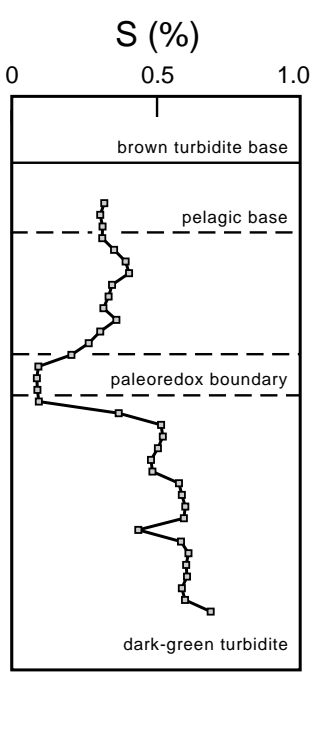

Figure 4. Concentration vs. depth profiles for $\mathrm{CaCO}_{3}$ (open squares), $\mathrm{Al}_{2} \mathrm{O}_{3}$ (solid squares), $\mathrm{C}_{\text {org }}$, and $\mathrm{S}$ in Section 157-950A-26X-3. Lithologic shading indicates sediment color and ovals are burrows (dominantly Chondrites). Horizontal discontinuous lines in the Lithology column are diagenetic lamellae. Solid and discontinuous horizontal lines on the geochemical profiles are geochemical boundaries (see text for discussion).
The normalization technique may also be applied to conservative elements such as $\mathrm{K}, \mathrm{Sc}$, and Ti, which do not suffer appreciable diagenesis in these sediments. In this case, element/Al ratios (Fig. 6) reveal first the relative homogeneity of the selected turbidite (230.81231.17 mbsf). Second, significant compositional contrasts can be discerned between the studied unit and both the overlying turbidite base (230.70-230.74 mbsf) and the intercalated pelagic interval (230.75$230.80 \mathrm{mbsf}$ ). Geochemical variation within the pelagic sediment contrasts strongly with the homogeneity of the turbidite. An underlying assumption for the discussion of redox sensitive element/Al profiles below is that, at the time of turbidite emplacement, these profiles were originally relatively constant with depth, similar to those of present $\mathrm{K}, \mathrm{Sc}$, and $\mathrm{Ti}$ ratios.

\section{Elements Initially Immobilized in Oxic Conditions}

\section{Manganese and Iron}

At an active oxidation front, $\mathrm{Mn}$ and $\mathrm{Fe}$ are supplied from below in reduced form as $\mathrm{Mn}^{2+}$ and $\mathrm{Fe}^{2+}$ respectively, to be immobilized in oxic conditions as $\mathrm{Mn}$ and $\mathrm{Fe}$ oxyhydroxides. The oxyhydroxide peaks of both elements, therefore, are metastable when post-oxic conditions develop after the turbidite is isolated from oxygenated bottom waters. Oxyhydroxide peaks will then be reduced back to $\mathrm{Mn}^{2+}$ and $\mathrm{Fe}^{2+}$. The effective rate of reduction for this process in the deep sea appears to be variable. Thomson et al. (1986) demonstrated that element peaks formed in oxic conditions were largely dispersed following reduction on subsequent burial diagenesis within 125 k.y., but Finney et al. (1988) found that the process was still incomplete after 400 k.y.

Sharp Mn- and Fe-enrichment peaks are not found in Section 157950A-26X-3 (Table 2). By comparison with compositional extrapolations from the underlying unoxidized sediment, however, relative enrichments of both elements do exist within the former oxidized zone (see below). In contrast to oxyhydroxide immobilization mechanisms in oxic conditions, which are similar for $\mathrm{Fe}$ and $\mathrm{Mn}$, the available mechanisms for diagenetic enhancement of $\mathrm{Mn}$ and $\mathrm{Fe}$ in anoxic conditions are quite distinct.

In the case of Mn (Fig. 7), sediment above the relic redox front is apparently depleted in $\mathrm{Mn}$. Sorption of $\mathrm{Mn}^{2+}$ onto $\mathrm{CaCO}_{3}$ surfaces is the most important process that controls the mobility of $\mathrm{Mn}^{2+}$ in anoxic conditions (Boyle, 1983; Thomson et al. 1986; Middelburg et al. 1987). The plot of $\mathrm{MnO}$ vs. $\mathrm{CaCO}_{3}$ for the section (Fig. 8) reveals three principal clusters of data: the base of the overlying brown turbidite with $45 \% \mathrm{CaCO}_{3}$ and $\sim 1400 \mu \mathrm{g} / \mathrm{g} \mathrm{MnO}$; the unoxidized section of the green turbidite with $25 \% \mathrm{CaCO}_{3}$ and $750 \mu \mathrm{g} / \mathrm{g} \mathrm{MnO}$; and the 
Figure 6. Concentration ratio vs. depth profiles for $\mathrm{K} / \mathrm{Al}$, $\mathrm{Sc} / \mathrm{Al}\left(\times 10^{4}\right)$, and Ti/Al in Section 157-950A-26X-3. Profiles reveal the vertical homogeneity of the studied turbidite, and the compositional contrasts with the overlying pelagic marly clay and brown turbidite.

Figure 7. $\mathrm{MnO}$ compared to $\mathrm{Mn} / \mathrm{Al}$ and $\mathrm{Mn} / \mathrm{Ca}$ ratios vs. depth in Section 157-950A-26X-3.
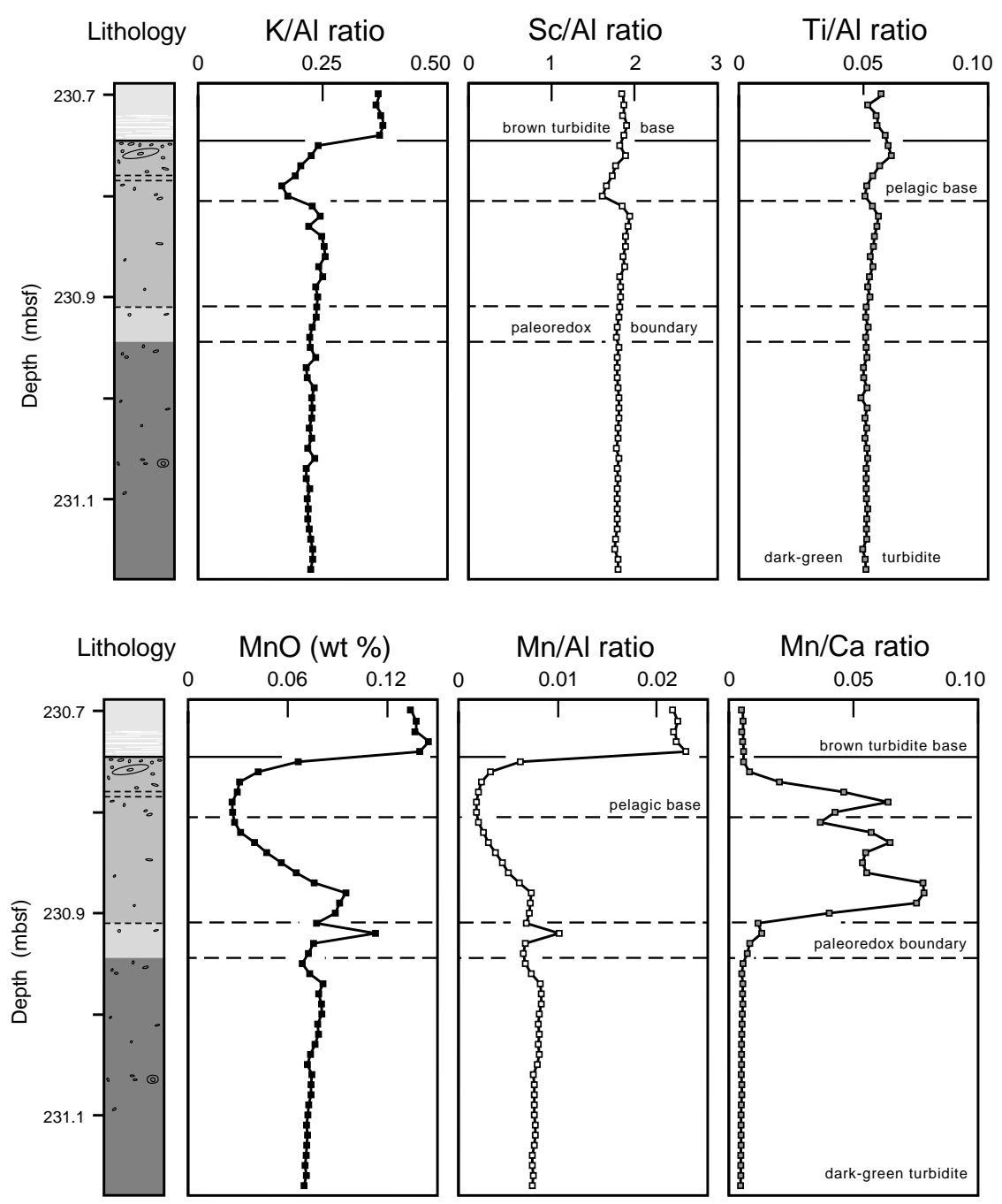

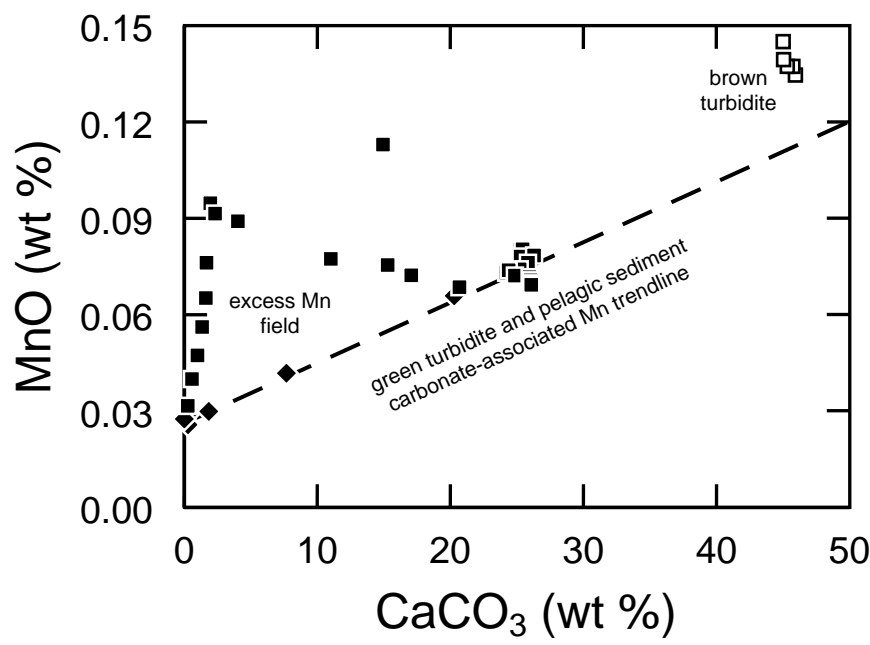

Figure $8 . \mathrm{MnO}$ vs. $\mathrm{CaCO}_{3}$ in Section 157-950A-26X-3. Filled squares = green turbidite, open squares = brown turbidite sample; and filled diamonds $=$ pelagic sediment lowest $\mathrm{MnO}$ values of $\sim 300 \mu \mathrm{g} / \mathrm{g}$ in the nearly $\mathrm{CaCO}_{3}$ free clay at the turbidite top. The $\mathrm{MnO}$ content now observed in the green turbidite is therefore controlled more by $\mathrm{CaCO}_{3}$ content than clay content, because the clay $\mathrm{MnO}$ content is very low $(\sim 300 \mu \mathrm{g} / \mathrm{g}$ compared with an "average" shale $\mathrm{MnO}$ content of $1100 \mu \mathrm{g} / \mathrm{g}$; Turekian and Wedepohl, 1961). A different $\mathrm{MnO}$ vs. $\mathrm{CaCO}_{3}$ relationship (Fig. 8) must apply in the brown turbidite, which exhibits a higher $\mathrm{Mn} / \mathrm{Ca}$ ratio.

Despite low absolute $\mathrm{MnO}$ values in the formerly oxidized section of the green turbidite (Fig. 7), there is actually more $\mathrm{MnO}$ present in this interval than anticipated from the relationship with $\mathrm{CaCO}_{3}$ content noted elsewhere in the same bed. $\mathrm{MnO}$ data from the formerly oxidized section also exhibit two different proportionalities with $\mathrm{CaCO}_{3}$. It appears likely that the Mn excess in this interval has been sourced from reduction of the $\mathrm{Mn}$ oxyhydroxide peak initially present. If this inference of $\mathrm{Mn}$ source is correct, it demonstrates that $\mathrm{CaCO}_{3}$ sorption has sequestered the $\mathrm{Mn}$ for the past $7 \mathrm{~m}$.y. This is consistent with laboratory sorption experiments that indicate the Mn phase on calcite behaves like a surface precipitate (Zachara et al., 1991).

There is a marked enrichment of $\mathrm{Fe}$ in the formerly oxidized section of the turbidite (Fig. 9) at 230.81-230.95 mbsf, compared with the lower unit (>230.95 mbsf). This enrichment amounts to $\sim 1 \%$ of the sediment when calculated as excess $\mathrm{Fe}$ over the lowest single $\mathrm{Fe} /$ $\mathrm{Al}$ value measured (Fig. 9). In the case of Fe, the formation of sulfides is the principal mechanism for immobilization of $\mathrm{Fe}^{2+}$ in anoxic conditions (Berner, 1982). As discussed above, however, there is little evidence of post-depositional sulfide formation in this turbidite. The $\mathrm{Fe} / \mathrm{S}$ ratios within the oxidized turbidite are in fact higher than 


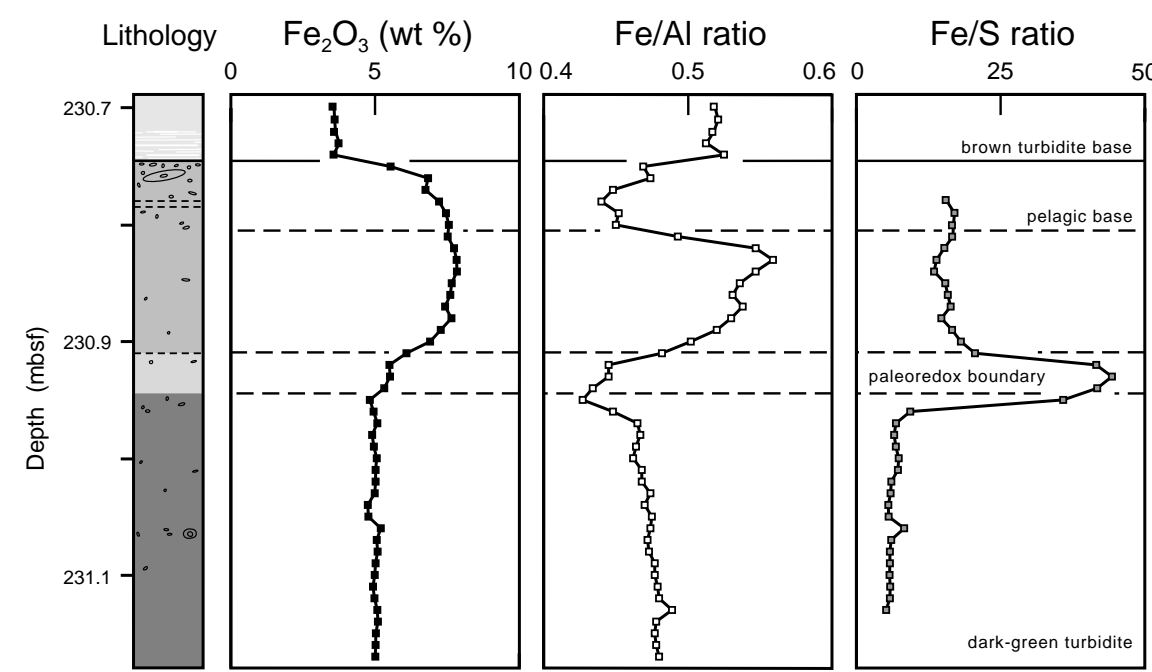

Figure 9. Total iron $\left(\mathrm{Fe}_{2} \mathrm{O}_{3}\right)$ compared to $\mathrm{Fe} / \mathrm{Al}$ and $\mathrm{Fe} / \mathrm{S}$ ratios vs. depth in Section 157-950A-26X-3. those below the redox front (Fig. 9), while sulfur depletion at the color transition produces a major Fe/S maximum at that level; there is insufficient $\mathrm{S}$ present in the formerly oxic top of the unit for sulfides to be the primary control on the observed Fe enrichment, as either $\mathrm{FeS}$ or $\mathrm{FeS}_{2}$. Indeed, the true $\mathrm{Fe} / \mathrm{S}$ ratios must be slightly lower than those reported, since a small contribution is included from residual pore-water sulfate.

Another possible fixation mechanism for $\mathrm{Fe}$, is the formation of diagenetic Fe silicates. The importance of this reaction in post-oxic deep-sea sediments has been inferred from pore-water systematics, rather than demonstrated through investigation of the new diagenetic phase. From consideration of observed gradients and concentrations in pore-water profiles, De Lange and Rispens (1986) and Winters and Buckley (1986) demonstrated independently that simultaneous uptake of both Fe and silica from solution must take place. Using electron microscopy, De Lange and Rispens (1986) observed amorphous authigenic mineral flakes that they believed might be Fe-rich nontronite. No Si data were collected in the present study, so the possibility of Fe silicate formation in Section 157-950A-26X-3 will require further specific investigation. Neither Mn nor Fe appears to be controlling any other element.

\section{Elements Initially Immobilized in Post-oxic Conditions}

Whereas oxidized $\mathrm{Fe}$ and $\mathrm{Mn}$ species are immobilized to form peaks at active oxidation fronts, it is the reduced forms of other elements that form peaks in post-oxic conditions (i.e., below Fe). Another major difference between such peaks and those of Fe and Mn, is that reduced species peaks must continuously move downward with the progress of the active redox front in order to maintain their position immediately below the oxic/post-oxic interface. So long as oxidation progresses downward, such peaks are continuously destroyed by oxidation only to be reformed deeper in the sediment by reduction. This implies that the peaks are formed of highly labile fractions of the elements concerned. Nevertheless, this set of element peaks is most likely to persist on subsequent burial, at least for as long as post-oxic conditions are maintained. Certain groupings or associations can be discerned.

\section{Antimony, Cadmium, Selenium, Thallium, and Vanadium}

On visual evidence (Figs. 3, 4), the oxidation front penetrated this turbidite to the color change and $\mathrm{C}_{\text {org }}$ step now at $230.95 \mathrm{mbsf}$. The elements $\mathrm{Cd}, \mathrm{Sb}, \mathrm{Se}, \mathrm{Tl}$, and $\mathrm{V}$ have peak maxima in their respective profiles close to this level (Fig. 10), although these maxima are not exactly coincident. The Se maximum is at $230.95 \mathrm{mbsf}$, the $\mathrm{Cd}, \mathrm{Sb}$, and $\mathrm{V}$ maxima are coincident at $230.96 \mathrm{mbsf}$, and the Tl peak maximum is at $230.97 \mathrm{mbsf}$. The peak shapes of the different elements are also different. That for $\mathrm{Cd}$ is particularly sharp and contained within a single 1-cm sample, the Se peak is essentially contained within 2 $\mathrm{cm}$, and those for $\mathrm{Tl}, \mathrm{Sb}$, and $\mathrm{V}$ are in well-defined peaks spread over $4 \mathrm{~cm}(\mathrm{~V})$ to $6 \mathrm{~cm}(\mathrm{Sb}, \mathrm{Tl})$. The data for all five elements are of sufficient precision to demonstrate that emplacement values below the relic redox front are higher than those in the formerly oxidized section above the peaks.

The interpretation of these profiles is that the five elements were already enriched in the turbidite sediment on emplacement, were released by oxidation, and then re-immobilized in post-oxic conditions in a downward direction to form the peaks. This is consistent with previous findings (Jarvis and Higgs, 1987; Thomson et al., 1993). Rosenthal et al. (1995) investigated the behavior of Cd at oxidation fronts in two recent turbidites, including that in core D11805\#1K. Although these workers also found that $\mathrm{Cd}$ was located in single sharp peaks, these peaks were actually broader than that observed here, where the extra $\mathrm{Cd}$ is in a single sample (Fig. 10) only $1 \mathrm{~cm}$ thick. The Cd-enriched zone in Section 157-950A-26X-3 might therefore be even thinner, and the enrichment correspondingly larger. Similarly, Thomson et al. (1993) observed that Se was located in a peak 5-6 cm thick, whereas the peak here is clearly contained within $2 \mathrm{~cm}$. The peak for Sb in core D11805\#1K was spread over $20 \mathrm{~cm}$, much broader than that seen in Section 157-950A-26X-3. In both cases, the V peak is of similar thickness. Thallium was not determined in core D11805\#1K. For these elements, therefore, the evidence is that the peaks in the selected turbidite are still in the positions achieved when the oxidation front that formed them terminated. There is no evidence of spreading in the subsequent 7 m.y. whatsoever; indeed, the enrichment peaks are sharper than those observed in the active case.

In more recent MAP examples, mass balances for $\mathrm{V}$ peaks reveal that they are too large to have been formed from recycling within the turbidite alone (Jarvis and Higgs, 1987; Thomson et al., 1993). Vanadium exists in seawater as a hydrated $\mathrm{V}(\mathrm{V})$ oxyanion at the relatively high concentration of $1 \mu \mathrm{g} / \mathrm{L}$. An additional V input can therefore be sourced from bottom waters, with insoluble reduced V(III) or V(IV) formed in anoxic conditions (Thomson et al., 1993). However, such an additional input is not required to form the profile in Section 157950A-26X-3. The remaining elements in this set (Cd, Sb, Se, and Tl) typically form sulfides, although a lack of correspondence between the sulfur and trace-metal profiles (Figs. 4, 10), demonstrates that, in this case, their distribution does not relate to the bulk sulfide content of the sediment.

\section{Cobalt, Copper, Nickel, and Zinc}

Of the elements $\mathrm{Co}, \mathrm{Cu}, \mathrm{Ni}$, and $\mathrm{Zn}$, only $\mathrm{Zn}$ has a secondary peak exactly at $230.96 \mathrm{mbsf}$ (Fig. 11), like Cd, Sb, and V. Copper has a local maximum immediately above at 230.95 mbsf coincident with Se. In both cases, these are the expected peak positions relative to the color change, as found in modern examples. 
This set of four elements, however, exhibits other peaks and, in particular, all display distinct and coincident peaks at $230.91 \mathrm{mbsf}$. As with Cd, Sb, Se, Tl, and V (Fig. 10), profiles for $\mathrm{Co}, \mathrm{Cu}, \mathrm{Ni}$, and $\mathrm{Zn}$ (Fig. 11) have generally lower values in the upper oxidized part of the turbidite compared with the lower part. A 1-mm-thick dark-purple band noted in the core description (Fig. 3; Table 2) is contained within the $230.91 \mathrm{mbsf}$ sample, $4 \mathrm{~cm}$ above the lower limit of oxidation. Such thin diagenetic bands with $\mathrm{Co}, \mathrm{Cu}, \mathrm{Ni}$, and $\mathrm{Zn}$ enrichment have not been observed in turbidites with active redox boundaries, but have been reported at MAP Quaternary fossil oxidation fronts (Jarvis and Higgs, 1987). Van Os et al. (1993) differentiated between black bands enriched in $\mathrm{Co}, \mathrm{Zn}, \mathrm{Ni}$, and $\mathrm{Cu}$ on the one hand, and purple bands with high $\mathrm{S}$ and $\mathrm{Cu}$ contents on the other. This distinction does not agree with the observation here, or with those of Jarvis and Higgs (1987), where purple bands were observed to contain $\mathrm{Co}, \mathrm{Cu}$, $\mathrm{Ni}$, and $\mathrm{Zn}$. If the enrichments for $\mathrm{Co}, \mathrm{Cu}, \mathrm{Ni}$, and $\mathrm{Zn}$ (Fig. 11) are located solely within the 1-mm dark-purple band, rather than the whole $1-\mathrm{cm}$ sample, then peak concentrations in the purple band itself may be an order of magnitude higher than the measured values. Three further thin, dark gray, bands showing clear $\mathrm{Cu}$ enrichment exist, one immediately under the base of the brown turbidite $(230.75$ mbsf), and two together within the pelagic interval (230.78 mbsf).
These bands do not have a consistent association with $\mathrm{Co}, \mathrm{Zn}$, and $\mathrm{Ni}$ (Fig. 11), although the uppermost has a Co association and the lower pair a $\mathrm{Zn}$ association.

Van Os et al. (1993) noted that the suite of elements $\mathrm{Co}, \mathrm{Cu}, \mathrm{Ni}$, and $\mathrm{Zn}$ is commonly found associated with $\mathrm{Mn}$ and $\mathrm{Fe}$ oxides (cf. Piper, 1988). The most likely hydroxide source for the band at 230.95 mbsf, therefore, would be the diagenetic oxyhydroxides previously present at the oxidation front. Hydrogenous oxyhydroxides might have been present in the pelagic sediment to source the bands at 230.75 and 230.78 mbsf.

Besides their association with oxyhydroxides, another chemical similarity between $\mathrm{Co}, \mathrm{Cu}, \mathrm{Ni}$, and $\mathrm{Zn}$ is their ready formation of soluble sulfide species (Luther et al., 1996). For $\mathrm{Cu}$ and $\mathrm{Zn}$, which both exhibit two peaks, maxima are located immediately above and at the base of a 4-cm-thick zone with lowest $\mathrm{S}$ contents measured in the section ( $900 \mu \mathrm{g} / \mathrm{g}$; Fig. 4, 230.92-230.96 mbsf). These low S contents are the cause of the high $\mathrm{C}_{\text {org }} / \mathrm{S}$ and $\mathrm{Fe} / \mathrm{S}$ ratios in Figures 5 and 9. The significance of this low-S zone is not clear, but such a distinct minimum is not observed in the $\mathrm{S}$ profile of the active case from core D11805\#1K (Thomson et al., 1993, fig. 8). It is possible that the purple band is a feature that developed after cessation of the oxidation front, possibly by upward diffusion from the initial enrichment

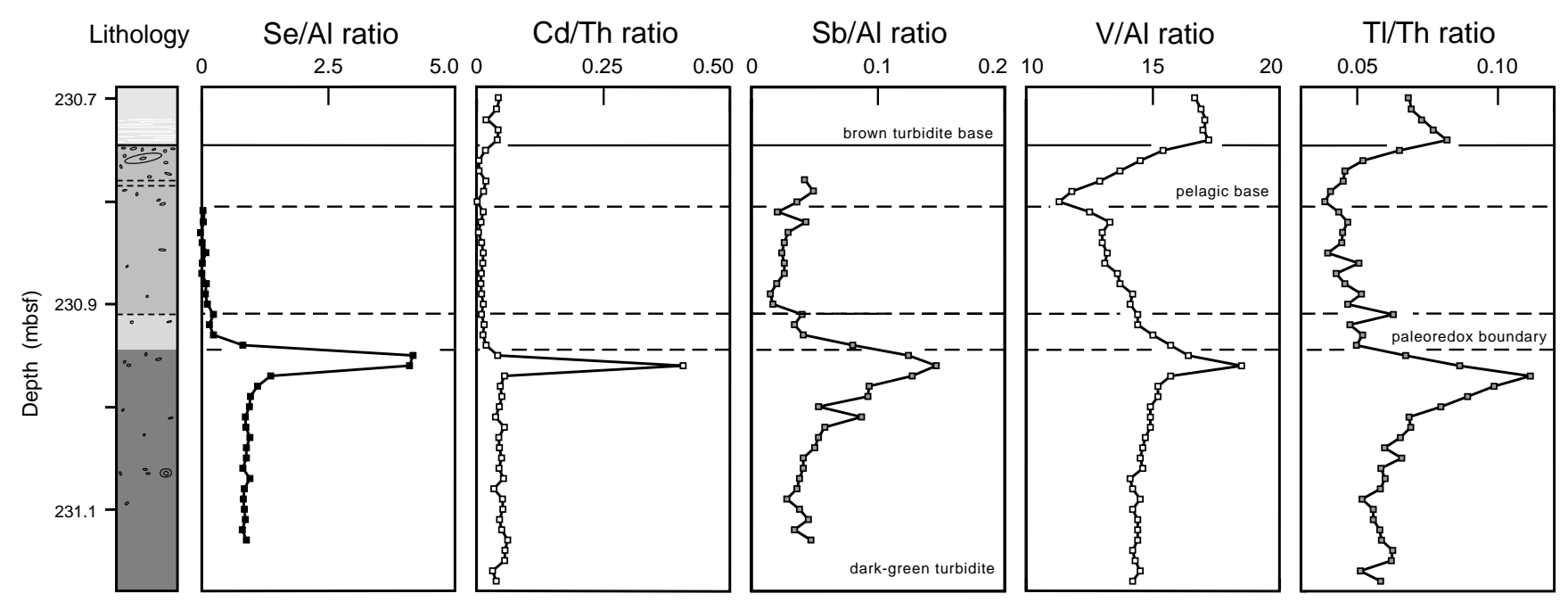

Figure 10. Se/Al, Cd/Th, Sb/Al, V/Al, and Tl/Th ratios vs. depth in Section 157-950A-26X-3 (Al ratios $\times 10^{4}$ ).

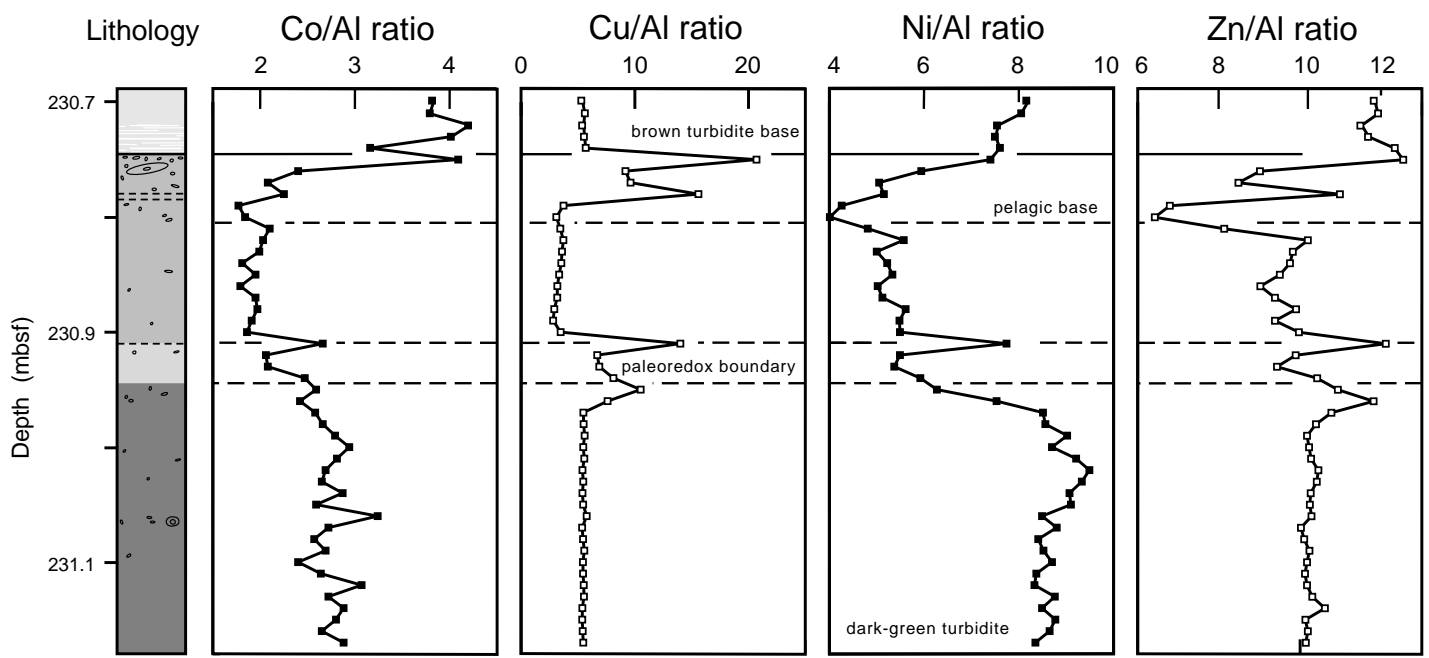

Figure 11. $\mathrm{Co} / \mathrm{Al}, \mathrm{Cu} / \mathrm{Al}, \mathrm{Ni} / \mathrm{Al}$, and $\mathrm{Zn} / \mathrm{Al}$ ratios $\left(\times 10^{4}\right)$ vs. depth in Section 157-950A-26X-3. 
around $230.96 \mathrm{mbsf}$, and that sulfides form an important component. Some microbiological cause for the migration and destruction of sulfide after termination of the progressive oxidation front is a possibility, although it is not clear why these four metals form a front at 230.91 mbsf.

\section{Arsenic and Uranium}

To a first approximation, the profiles of As and $U$ resemble those of $\mathrm{C}_{\text {org }}$ (Figs. 4, 12). Arsenic is a metalloid element like Se, Sb, and $\mathrm{Te}$, but it does not exhibit any peaks within the studied section. Arsenic levels, unlike those of $\mathrm{C}_{\text {org }}$, increase with depth in the unoxidized region of the unit, and the As profile broadly follows S (Fig. 12). In this case, it is likely that As(III) is associated with pyrite on emplacement and is liberated on pyrite oxidation as the oxidized $\mathrm{As}(\mathrm{V})$ species $\mathrm{AsO}_{4}{ }^{3-}$. No subsequent immobilization of As is evident in the investigated portion of Section 157-950A-26X-3.

Similarly, the U profile has no clear peak, but instead has a stepped profile (Fig. 12), similar to that of $\mathrm{C}_{\mathrm{org}}$ (Fig. 4). Uranium was the first element that was shown to have a peak in reduced conditions below an oxidation front in turbidite studies (Colley et al., 1984). The mechanism of $U$ uptake in reducing sediments is generally taken to be reduction of $\mathrm{U}(\mathrm{VI})$ from seawater, to $\mathrm{U}(\mathrm{V})$ or $\mathrm{U}(\mathrm{IV})$ in sediments (Klinkhammer and Palmer, 1991), and reoxidation by an oxidation front followed by reduction below the front is the suggested mechanism to form U peaks (Colley and Thomson, 1985). Of all the elements that form relocalizations at oxidation fronts, U-peak maxima are generally those located furthest below the color change, and $\mathrm{U}$ also has the most widely dispersed peaks (Jarvis and Higgs, 1987; Thomson et al., 1993). This spread first allowed U-enrichment peaks to be identified at low sampling resolution, but such broad peaks suggest that the immobilization mechanism for $U$ is not as efficient as those for the other elements discussed above. By comparison of $U$ profiles with those of its ingrown daughter radioisotopes, however, Colley and Thomson (1990) demonstrated that U peaks were nearimmobile over $0.5 \mathrm{~m}$.y. The U profile in the studied section is interpreted, therefore, as either a very diffuse peak (in Core D11805\#1K it was spread over $45 \mathrm{~cm}$; Thomson et al., 1993), or as evidence of very slight migration. If migration has occurred, there is no evidence of an upward spread into the region with low $\mathrm{C}_{\text {org }}$ levels.

\section{CONCLUSIONS}

Recognition criteria developed from studies of recent MAP organic-rich turbidites recovered by piston cores have been used to select a comparable late Miocene (7.6 Ma) example from Hole 950A for detailed investigation. Like its modern counterparts, the Miocene turbidite is characterized by a green two-tone coloration with dark lower and paler upper portions. The color contrast is the result of a diffusion-driven oxidation process that operated for only the first few tens of thousands of years after emplacement. Nevertheless, the contrast remains clear, despite the fact that it was deposited $\sim 7.6 \mathrm{Ma}$ and is now buried to $230 \mathrm{mbsf}$.

Marked $\mathrm{C}_{\text {org }}$ and $\mathrm{CaCO}_{3}$ contrasts are confirmed across the color change in the otherwise vertically homogenous turbidite, similar to those observed in more recent units, despite the fact that $\mathrm{C}_{\text {org }}$ remineralization must have continued in the section on subsequent burial. This conclusion follows from pore-water data, which demonstrate that after oxidation the selected unit progressed through post-oxic conditions, and is now in a sulfate-reducing environment. Although the pore-water data indicate that $\mathrm{SO}_{4}{ }^{2-}$ reduction remains active, no clear evidence of new sulfide formation in the selected unit could be ascertained from $\mathrm{C}_{\text {org }} / \mathrm{S}$ ratios. Low rates of sulfate reduction are also indicated by the fact that residual $\mathrm{SO}_{4}{ }^{2-}$ persists to the base of the drilled section (380 mbsf) at Site 950 .

There is evidence that $\mathrm{Fe}$ and $\mathrm{Mn}$, expected to have been precipitated as oxyhydroxides in oxic conditions at the active front, are still present in excess quantities in the formerly oxic zone. The controls on these excess quantities are likely to be sorption on $\mathrm{CaCO}_{3}$ for $\mathrm{Mn}$ as $\mathrm{Mn}(\mathrm{II})$, and Fe silicate rather than Fe sulfide formation.

Certain elements $(\mathrm{Cd}, \mathrm{Sb}, \mathrm{Se}, \mathrm{Tl}$, and $\mathrm{V})$ appear to have remained fixed in distinct peaks and are persistent geochemical indicators of the oxidation front process over $7 \mathrm{~m}$.y. The peak maxima for these different elements are not exactly coincident. This is believed to be a consequence of their individual responses to the redox gradient developed on the oxic/post-oxic boundary of the progressive oxidation front. Other elements $(\mathrm{Co}, \mathrm{Cu}, \mathrm{Ni}$, and $\mathrm{Zn})$ are inferred to have migrated together in a distinct purple band as sulfide complexes. Arsenic and $U$ have profiles which are similar to that of $\mathrm{C}_{\text {org }}$, so there is no evidence of remobilization of these elements within the section.

\section{ACKNOWLEDGMENTS}

We thank the crew, marine technicians, and fellow scientists of Leg 157 for their help and enthusiasm. In particular, Martine Gérard, Sten Lindblom, Anne Pimmel, and Robert Kemp managed to survive the shipboard geochemical program. Erinn McCarty remained jovial despite our persistent requests for difficult samples. Nigel Higgs provided advice on the analytical methods used in this paper. Thoughtful reviews of the manuscript were provided by Gert De Lange and Fred Prahl. We gratefully acknowledge support of this work through Natural Environment Research Council (NERC) ODP grant GST/02/ 1097 and access to the facilities of the NERC ICP-MS Unit.

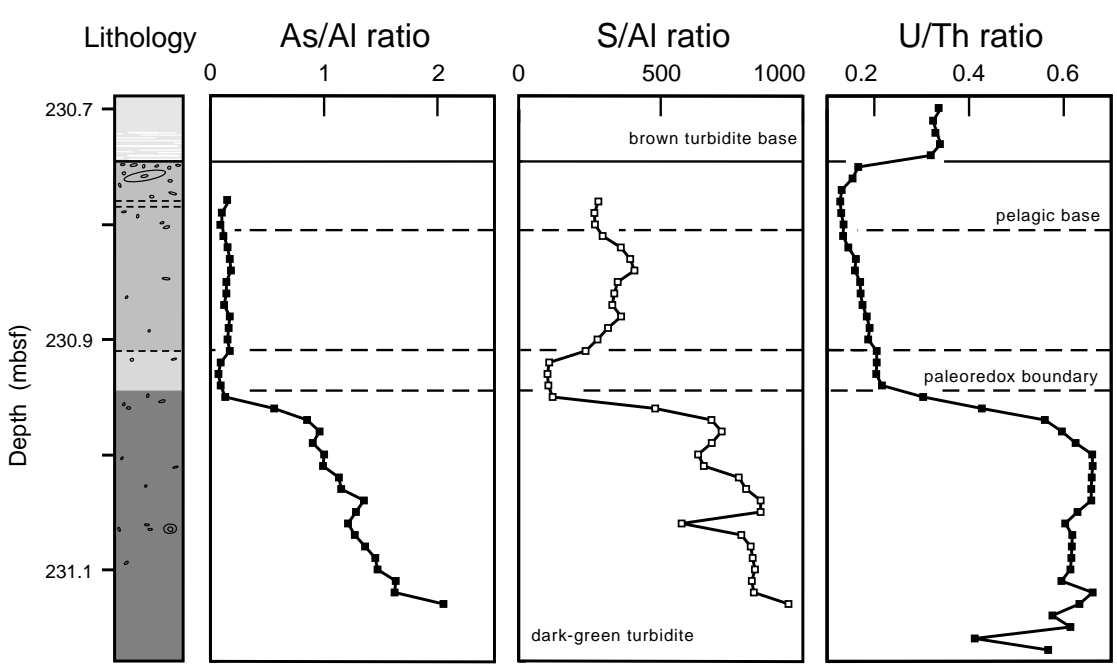

Figure 12. As/Al, S/Al, and U/Th ratios vs. depth in Section 157-950A-26X-3 (Al ratios $\times 10^{4}$ ). 


\section{REFERENCES}

Berner, R.A., 1981. A new geochemical classification of sedimentary environments. J. Sediment. Petrol., 51:359-365.

, 1982. Burial of organic carbon and pyrite sulfur in the modern ocean: its geochemical and environmental significance Am. J. Sci., 282:451-473

Boudreau, B.P., 1994. Is burial velocity a master parameter for bioturbation? Geochim. Cosmochim. Acta, 58:1243-1249.

Boyle, E.A., 1983. Manganese carbonate overgrowths on foraminifera tests. Geochim. Cosmochim. Acta., 47:1815-1819.

Buckley, D.E., and Cranston, R.E., 1988. Early diagenesis in deep sea turbidites: the imprint of paleo-oxidation zones. Geochim. Cosmochim. Acta, 52:2925-2939.

Colley, S., and Thomson, J., 1985. Recurrent uranium relocations in distal turbidites emplaced in pelagic conditions. Geochim. Cosmochim. Acta, 49:2339-2348.

1990. Limited diffusion of U-series radionuclides at depth in deep-sea sediments. Nature, 346:260-263.

, 1992. Behavior and mobility of U-series radionuclides in Madeira Abyssal Plain turbidites over the past 750,000 years. Mar. Geol., 109:141-158.

Colley, S., Thomson, J., and Toole, J., 1989. Uranium relocations and derivation of quasi-isochrons for a turbidite/pelagic sequence in the Northeast Atlantic. Geochim. Cosmochim. Acta, 53:1223-1234.

Colley, S., Thomson, J., Wilson, T.R.S., and Higgs, N.C., 1984. Post-depositional migration of elements during diagenesis in brown clay and turbidite sequences in the North East Atlantic. Geochim. Cosmochim. Acta, 48:1223-1235.

Colodner, D.C., Boyle, E.A., Edmond, J., and Thomson, J., 1992. Post-depositional mobility of platinum, iridium and rhenium in marine sediments. Nature, 358:402-404

Cowie, G.L., Hedges, J.I., Prahl, F.G., and De Lange, G.J., 1995. Elemental and major biochemical changes across an oxidation front in a relict turbidite: an oxygen effect. Geochim. Cosmochim. Acta, 59:33-46.

Cranston, R.E., and Buckley, D.E., 1990. Redox reactions and carbonate preservation in deep-sea sediments. Mar. Geol., 94:1-8.

De Lange, G.J., 1992a. Distribution of exchangeable, fixed, organic and total nitrogen in interbedded turbiditic/pelagic sediments of the Madeira abyssal plain, eastern North Atlantic. Mar. Geol., 109:95-114.

, 1992b. Distribution of various extracted phosphorus compounds in the interbedded turbiditic/pelagic sediments of the Madeira Abyssal Plain, eastern North Atlantic. Mar. Geol., 109:115-139.

De Lange, G.J., Jarvis, I., and Kuijpers, A., 1987. Geochemical characteristics and provenance of late Quaternary sediments from the Madeira Abyssal Plain, North Atlantic. In Weaver, P.P.E., and Thomson, J. (Eds.), Geology and Geochemistry of Abyssal Plains. Geol. Soc. Spec. Publ. London, 31:147-165.

De Lange, G.J., Middelburg, J.J., Jarvis, I., and Kuijpers, A., 1989. Geochemical characteristics and provenance of late Quaternary sediments from the Madeira and southern Nares Abyssal Plains (North Atlantic). In Schuttenhelm, R.T.E., Auffret, G.A., Buckley, D.E., Cranston, R.E., Murray, C.N., Shephard, L.E., and Spijkstra, A.E. (Eds.), Geoscience Investigations of Two North Atlantic Abyssal Plain-The ESOPE International Expedition: Luxembourg (Commission of the European Community), 2:785-851.

De Lange, G.J., and Rispens, F.B., 1986. Indication of a diagenetically induced precipitate of an Fe-Si mineral in sediment from the Nares Abyssal Plain, western North Atlantic. Mar. Geol., 73:85-97.

Emery, D., and Robinson, A., 1993. Inorganic Geochemistry: Applications to Petroleum Geology: Oxford (Blackwell)

Finney, B.P., Lyle, M.W., and Heath, G.R., 1988. Sedimentation at MANOP Site H (eastern equatorial Pacific) over the past 400,000 years: climatically induced redox variations and their effects on transition metal cycling. Paleoceanography, 3:169-189.

Froelich, P.N., Klinkhammer, G.P., Bender, M.L., Luedtke, N.A., Heath, G.R., Cullen, D., Dauphin, P., Hammond, D., Hartman, B., and Maynard, V., 1979. Early oxidation of organic matter in pelagic sediments of the eastern equatorial Atlantic: suboxic diagenesis. Geochim. Cosmochim. Acta, 43:1075-1090

Gieskes, J.M., Gamo, T., and Brumsack, H., 1991. Chemical methods for interstitial water analysis aboard JOIDES Resolution. ODP Tech. Note, 15.
Jarvis, I., 1992. Sample preparation for ICP-MS. In Jarvis, K.E., Gray, A.L., and Houk, R.S. (Eds.), Handbook of Inductively Coupled Plasma Mass Spectrometry: Glasgow (Blackie), 172-224.

Jarvis, I., and Higgs, N., 1987. Trace-element mobility during early diagenesis in distal turbidites: late Quaternary of the Madeira Abyssal Plain, N Atlantic. In Weaver, P.P.E., and Thomson J. (Eds.), Geology and Geochemistry of Abyssal Plains. Geol. Soc. Spec. Publ. London, 31:179214.

Keil, R.G., Hu, F.S., Tsamakis, E.C., and Hedges, J.I., 1994. Pollen in marine sediments as an indicator of oxidation of organic matter. Nature, 369:639-641.

Kennedy, H.A., and Elderfield, J., 1987. Iodine diagenesis in non-pelagic deep sea sediments. Geochim. Cosmochim. Acta, 51:2505-2514.

Klinkhammer, G.P., and Palmer, M.R., 1991. Uranium in the oceans: where it goes and why. Geochim Cosmochim Acta, 55:1799-1806.

Kuldvere, A., 1989. Extraction of geological materials with mineral acids for the determination of $\mathrm{As}, \mathrm{Sb}, \mathrm{Bi}$, and $\mathrm{Se}$ by hydride generation atomic absorption spectrometry. Analyst, 114:125-131.

Lowrie, W., Alvarez, W., and Asaro, F., 1990. The origin of the White Beds below the Cretaceous-Tertiary boundary in the Gubbio section, Italy. Earth Planet. Sci. Lett., 98:303-312.

Luther, G.W., III, Rickard, D.T., and Olroyd, A., 1996. Determination of metal (bi)sulfide stability constants of $\mathrm{Mn}^{2+}, \mathrm{Fe}^{2+}, \mathrm{Co}^{2+}, \mathrm{Ni}^{2+}, \mathrm{Cu}^{2+}$, and $\mathrm{Zn}^{2+}$ by voltammetric methods. Environ. Sci. Technol., 30:671-679.

Manheim, F.T., and Sayles, F.L., 1974. Composition and origin of interstitial waters of marine sediments, based on deep sea drill cores. In Goldberg, E.D. (Ed.), The Sea (Vol. 5): Marine Chemistry: The Sedimentary Cycle: New York (Wiley), 527-568

McArthur, J.M., Tyson, R.V., Thomson, J., and Mattey, D., 1992. Early diagenesis of marine organic matter: alteration of the carbon isotopic composition. Mar. Geol., 105:51-61.

Middelburg, J.J., 1993. Turbidites provide a unique opportunity to study diagenetic processes. Geol. Mijnbouw, 72:15-21.

Middelburg, J.J., De Lange, G.J., and Van der Weijden, C.H., 1987. Manganese solubility control in marine pore waters. Geochim. Cosmochim. Acta, 51:759-763.

Pearce, T.J., and Jarvis, I., 1995. High-resolution chemostratigraphy of Quaternary distal turbidites: a case study of new methods for the analysis and correlation of barren sequences. In Dunay, R.E., and Hailwood, E.A. (Eds.), Non-biostratigraphical Methods of Dating and Correlation. Geol. Soc. Spec. Publ. London, 89:107-143.

Piper, D.Z., 1988. The metal oxide fraction of pelagic sediment in the equatorial North Pacific Ocean: a source of metals in ferromanganese nodules. Geochim. Cosmochim. Acta, 52:2127-2145.

Prahl, F.G., De Lange, G.J., Lyle, M., and Sparrow, M.A., 1989. Post-depositional stability of long-chain alkenones under contrasting redox conditions. Nature, 341:434-437.

Rosenthal, Y., Lam, P., Boyle, E.A., and Thomson, J., 1995. Authigenic cadmium enrichments in suboxic sediments: precipitation and postdepositional mobility. Earth Planet. Sci. Lett., 132:99-111.

Schmincke, H.-U., Weaver, P.P.E., Firth, J.V., et al., 1995. Proc. ODP, Init. Repts., 157: College Station, TX (Ocean Drilling Program).

Thomson, J., Colley, S., Higgs, N.C., Hydes, D.J., Wilson T.R.S., and Sorensen, J., 1987. Geochemical oxidation fronts in NE Atlantic distal turbidites and their effects in the sedimentary record. In Weaver, P.P.E., and Thomson, J. (Eds.), Geology and Geochemistry of Abyssal Plains. Geol. Soc. Spec. Publ. London, 31:167-177.

Thomson, J., Higgs, N.C., and Colley, S., 1989. A geochemical investigation of reduction haloes developed under turbidites in brown clay. Mar. Geol., $89: 325-330$.

Thomson, J., Higgs, N.C., Croudace, I.W., Colley, S., and Hydes, D.J., 1993. Redox zonation of elements at an oxic/post-oxic boundary in deep-sea sediments. Geochim. Cosmochim. Acta, 57:579-595.

Thomson, J., Higgs, N.C., Jarvis, I., Hydes, D.J., Colley, S., and Wilson, T.R.S., 1986. The behaviour of manganese in Atlantic carbonate sediments. Geochim. Cosmochim. Acta, 50:1807-1818.

Turekian, K.K., and Wedepohl, K.H., 1961. Distribution of the elements in some major units of the earth's crust. Geol. Soc. Am. Bull., 72:175-192.

van Os, B., Visser, H.-J., Middelburg, J.J., and De Lange, G.J., 1993. Occurrence of thin, metal-rich layers in deep-sea sediments: a geochemical characterization of copper mobilization. Deep-Sea Res., 40:1713-1730.

Wallace, M.W., Gostin, V.A., and Keays, R.R., 1990. Acraman impact ejecta and host shales: evidence for low-temperature mobilization of iridium and other platinoids. Geology, 18:132-135. 
Wang, K., Attrep, M., Jr., and Orth, C.J., 1993. Global iridium anomaly, mass extinction, and redox change at the Devonian-Carboniferous boundary. Geology, 21:1071-1074.

Waples, D.W., and Sloan, J.R., 1980. Carbon and nitrogen diagenesis in deep sea sediments. Geochim. Cosmochim. Acta, 44:1463-1470.

Weaver, P.P.E., and Rothwell, R.G., 1987. Sedimentation on the Madeira Abyssal Plain over the last 300,000 years. In Weaver, P.P.E., and Thomson, J. (Eds.), Geology and Geochemistry of Abyssal Plains. Geol. Soc. Spec. Publ. London, 31:71-86.

Weaver, P.P.E., Rothwell, R.G., Ebbing, J., Gunn, D., and Hunter, P.M., 1992. Correlation, frequency of emplacement and source directions of megaturbidites on the Madeira Abyssal Plain. Mar. Geol., 109:1-20.

Weaver, P.P.E., Thomson, J., and Jarvis, I. 1989. The geology and geochemistry of Madeira Abyssal Plain sediments: a review. In Freeman, T.J. (Ed.), Advances in Underwater Technology, Ocean Science and Offshore Engineering (Vol. 18): London (Graham and Trotman), 51-78.

Wilson, T.R.S., Thomson, J., Colley, S., Hydes, D.J., Higgs, N.C., and Sørensen, J., 1985. Early organic diagenesis: the significance of progres- sive subsurface oxidation fronts in pelagic sediments. Geochim. Cosmochim. Acta., 49:811-822.

Wilson, T.R.S, Thomson, J., Hydes, D.J., Colley, S., Culkin, F., and Sørensen, J., 1986. Oxidation fronts in pelagic sediments: diagenetic formation of metal-rich layers. Science, 232:972-975.

Winters, G.V., and Buckley, D.E., 1986. The influence of dissolved $\mathrm{FeSi}_{3} \mathrm{O}_{3}(\mathrm{OH})_{3}{ }^{0}$ on chemical equilibria in pore waters from deep sea sediments. Geochim. Cosmochim. Acta, 50:277-288.

Zachara, J.M., Cowan, C.E., and Resch, C.T., 1991. Sorption of divalent metals on calcite. Geochim. Cosmochim. Acta, 55:1549-1562.

Date of initial receipt: 8 July 1996

Date of acceptance: 10 January 1997

Ms 157SR-130 